\title{
Antimicrobial Photoinactivation Approach Based on Natural Agents for Control of Bacteria Biofilms in Spacecraft
}

\author{
Irina Buchovec ${ }^{1, *}$, Alisa Gricajeva ${ }^{2, *}$, Lilija Kalèdienè ${ }^{2}$ and Pranciškus Vitta ${ }^{1}$ \\ 1 Institute of Photonics and Nanotechnology, Faculty of Physics, Vilnius University, Sauletekio av. 3, \\ LT-10257 Vilnius, Lithuania; pranciskus.vitta@ff.vu.lt \\ 2 Department of Microbiology and Biotechnology, Institute of Biosciences, Life Sciences Center, \\ Vilnius University, Sauletekio av. 7, LT-10257 Vilnius, Lithuania; lilija.kalediene@gmc.vu.lt \\ * Correspondence: irina.buchovec@ff.vu.lt (I.B.); alisa.gricajeva@gmc.vu.lt (A.G.)
}

Received: 31 August 2020; Accepted: 17 September 2020; Published: 21 September 2020

\begin{abstract}
A spacecraft is a confined system that is inhabited by a changing microbial consortium, mostly originating from life-supporting devices, equipment collected in pre-flight conditions, and crewmembers. Continuous monitoring of the spacecraft's bioburden employing culture-based and molecular methods has shown the prevalence of various taxa, with human skin-associated microorganisms making a substantial contribution to the spacecraft microbiome. Microorganisms in spacecraft can prosper not only in planktonic growth mode but can also form more resilient biofilms that pose a higher risk to crewmembers' health and the material integrity of the spacecraft's equipment. Moreover, bacterial biofilms in space conditions are characterized by faster formation and acquisition of resistance to chemical and physical effects than under the same conditions on Earth, making most decontamination methods unsafe. There is currently no reported method available to combat biofilm formation in space effectively and safely. However, antibacterial photodynamic inactivation based on natural photosensitizers, which is reviewed in this work, seems to be a promising method.
\end{abstract}

Keywords: antibacterial photoinactivation; natural photosensitizers; spacecraft biofilm decontamination

\section{Introduction}

A spacecraft is a closed system inhabited by microorganisms originating from life support systems, cargo, and most importantly, crewmembers [1-3]. Microorganisms found in the spacecraft are exposed to unique selective pressures such as microgravity, space radiation, elevated carbon dioxide levels, hypomagnetic conditions, and continuous human habitation [4]. It has been shown that sometimes these conditions provoke unusual bacterial traits, such as the faster acquirement of antibiotic, chemical, and physical resistance; faster biofilm formation; and altered growth kinetics compared to Earth conditions [5-7]. The microbiome of the confined spacecraft environment needs to be examined constantly to identify the species of microorganisms that can accumulate in this unique environment, which can change and survive under stress conditions as free-living cells or most importantly as biofilms, and which can influence human health, spacecraft infrastructure, and material integrity. Such findings could help to find the best way of controlling microorganisms in such environments and enable safe, long-duration space missions. In the period since the first taxonomical and quantitative studies of spacecraft microbiomes, culture-dependent and later culture-independent studies have revealed a broad range of microbial loads. The most comprehensive study of the microbes that are able to survive in spacecraft was carried out at the International Space Station (ISS). All of the bacteria detected in the spacecraft can be divided into three groups: (1) potentially pathogenic 
bacteria; (2) technophilic bacteria, and (3) bacteria that do not affect crewmembers' health or the equipment. Analysis of the scientific literature describing the microbiological bioburden of spacecraft has shown that in the majority of the studies, certain bacterial taxonomic groups prevail among others. The most abundant airborne bacteria in spacecraft, as determined by conventional culture methods and cultivation-independent molecular methods, are identified as Enterobacteriaceae, Staphylococcus spp., Bacillus spp., Corynebacterium spp., and Propionibacterium spp. The most frequent potable water-system species in most cases were reported to belong to Methylobacterium spp., Sphingomonas spp. (particularly Sphingomonas paucimobilis), Cupriavidus spp., Chryseobacterium spp., and Ralstonia spp. [8-12]. Most of the above mentioned bacteria are human-associated, usually found on human skin, and are determined to be responsible for the formation and diversity of spacecraft microbiota. The most significant equipment damage was reported to be caused by Bacillus spp. and several mold species [3,13].

The most abundant bacteria found in the spacecraft are most likely to form biofilms. Bacterial biofilms in the spacecraft usually form on hard-to-clean, moist areas such as piping and equipment behind panels, electrical connectors, thermal control system radiators, the water recycling system, and the rubber of hatch locks, etc., which could be dangerous for both spacecraft equipment and human health $[3,4,11,13]$. However, some recent studies suggest that ISS conditions are selective but do not alter microbial characteristics relevant to human health. Therefore, according to the latest research on the development of bacterial biofilm in space conditions, this bacterial mode of growth is currently considered to pose a higher threat to the spacecraft material integrity than the crewmembers' health $[1,3,14]$. Nevertheless, the fact that biofilms were shown to form more quickly in spaceflight conditions and to form thicker, different unique structures than on Earth $[3,5,6]$, the impact of the bacterial biofilms on the spacecraft's crew health must be studied in more detail, using suitable techniques in order to draw more definitive conclusions.

Since the environment of space in some cases alters bacterial biofilms through increasing their chemical and physical resilience, the development of alternative technologies could be the first efficient step towards the safe reduction of this critical problem in spacecraft. In this context, the antimicrobial photoinactivation (API) approach seems to be one of the most promising strategies. API is a biophotonic technology involving the employment of a photoactive compound (a photosensitizer (PS)) that selectively accumulates in the target cells, which are then illuminated $[15,16]$. The interaction of the PS and light in the presence of oxygen results in a plethora of cytotoxic reactions. Usually, after light excitation, the triplet-state of the PS interacts with molecular oxygen, electron donors, or acceptors and can produce reactive oxygen species (ROS), thereby triggering photo-oxidative reactions that initiate various forms of cellular damage, thus destroying the bacterial cells [17].

The antibacterial efficiency of API is influenced by many factors, but especially by the physicochemical properties of the PS chosen. Many significant advances have been made in PS research during the last 20 years. It has been reported that API is effective in eradicating both planktonic cells and biofilms of bacteria. A wide range of compounds of different structures can be applied, and the efficacy of some PSs has already been evaluated for the eradication of biofilms. Generally, phenothiazinium dyes (e.g., Methylene Blue, Toluidine Blue), porphyrins (e.g., TMPyP), and xanthene dyes (e.g., Erythrosine and Rose Bengal) have been used for API applications [18,19]. There are several advantages of the API method for the control of bacteria biofilms in specific, confined spacecraft environments: (1) API belongs to a multitarget process, so no development of bacterial resistance occurs; (2) microbial killing is rapid (occurs within seconds); and (3) broad-spectrum action removes the need to identify the particular pathogen (identification is difficult to perform in the space environment). Unfortunately, not all mentioned dye-based PSs are effective and can be unsafe to use in spacecraft. For the application of API in the spacecraft environment, it is necessary to use PSs which are chemically pure and easy to produce, water-soluble, and non-bleaching, with a stable shelf-life, and most importantly which are safe, meaning that they must not alter the crewmembers' health $[19,20]$. Compared with synthetic PSs, naturally occurring agents are of great interest due to the variety of their molecular structure and specific biological activities. Analysis of the literature 
regarding the application of API to control bacterial biofilms shows that a large number of natural products and their derivatives have significant photodynamic activities, and some of them have been clinically applied. There are several main natural products that can be used in API—some of the most commonly used are curcumin (CUR), riboflavin (RF), perylenequinones (hypericin (Hyp), hypocrellin), psoralens, and chlorophyll derivatives (sodium chlorophyllin (Chl)) $[16,18,21]$. The emergence of new detection and analysis technologies raises the possibility of the rapid identification of potent PSs derived from natural products, and the extension of the application of already known natural agents.

\section{Biofilms in Spacecraft}

Bacterial free-living (planktonic) cells are able to switch to the biofilm mode of growth-a sessile and structured three-dimensional community of microorganisms on a surface, encapsulated in a self-formed matrix made of extracellular polymeric substances (EPS) [22,23]. Biofilm formation is considered to be a default mode of growth, enabling bacteria to sequester in a nutrient-rich area, utilize the cooperative benefits of living in a community, and protect themselves from harmful conditions [24]. Usually, these bacterial consortia are associated with moist, hard-to-clean surfaces. The properties of microorganisms living within a biofilm generally differ substantially from those of microorganisms of the same species existing independently [25]. The presence of biofilm makes bacteria more resilient and non-responsive to the treatments currently used [26]; once established, biofilms become highly resistant to various chemicals (antibiotics, antimicrobial disinfectants, etc.) and physical effects. Therefore, biofilm-associated microbial harm poses a severe threat not only in the hospital and industrial settings on Earth but also in confined areas such as the ISS or other spacecraft. Although spacecraft are assembled in cleanrooms in order to minimize microbial contamination, some microorganisms withstand and survive decontamination methods applied in ultraclean facilities. These microorganisms are more often referred to as extremophiles that can deteriorate abiotic surfaces and do not endanger the crew's health. A greater risk to crewmembers in the spacecraft may arise from microbes originating from their own microbiota, water, and food supplies [11,14]. The diversity and abundance of microorganisms from surfaces, air filters, and potable water systems on the ISS have been studied in detail, and human-associated bacteria were found to be the most frequently isolated, therefore comprising a set of microorganisms which are most likely to form biofilms in spacecraft $[8,27-35]$. Isolates from the ISS are able to grow as biofilms under standard laboratory conditions, suggesting that the capacity to form complex communities on surfaces and interfaces provides a competitive advantage aboard spacecraft [11]. Biofilms may play an important role in human infections and create a potential threat towards material integrity, especially in terms of long-term space missions, since the extent and complexity of microbial contamination are increasing with time [1,11]. Thus, the microbiome of the closed space environment needs to be examined comprehensively in order to identify microorganisms that can accumulate in this unique environment, survive under stress conditions in biofilms, and influence both human health and key equipment of the spacecraft. Such findings could help to find the best way of controlling biofilms in such environments and enable safe space missions that will lengthen over time due to the progress and expansion of human activity in space [3].

\subsection{Effects of Microbial Biofilms on Spacecraft Crew Health}

Microbial biofilm growth, increasing the risk of human illness and sometimes damaging key equipment such as spacesuits, water recycling units, radiators, and navigation windows, has been observed in Soviet/Russian (Salyut and Mir), American (Skylab) space stations, and the ISS. It is important to emphasize that spacecraft such as the ISS are confined and closed habitats, exposed to unique conditions such as cosmic radiation, microgravity, and hypomagnetism, and these conditions have a substantial effect on human and spacecraft microbiota [3,4,36,37]. Space conditions can affect the immune responses of the crewmembers by altering respiratory, gastrointestinal, and nasal bacterial microbiota, which may represent health risks for the crew. Thus, bacterial biofilms that form on the 
indoor equipment surfaces of spacecraft may pose an even a more significant threat to the human health [4]. In some of the early space station missions like Mir and Skylab, spaceflight crew members became ill in space. In-flight cross-contamination with Staphylococcus aureus and other pathogens in the upper respiratory tract of astronauts has since been reported [38]. In the US segment of the ISS, from December 2011 to July 2012, allergic responses to the cabin environment and dust in the Node 3 cabin were also reported. The latter findings led to a comprehensive study of particulate and debris samples from the ISS [2,11]. However, more recent studies suggest that ISS conditions are selective, but do not alter microbial characteristics relevant to human health [1]. Mora et al. (2019) reported the results of the ISS experiment "Extremophiles", which involved the study of microbial communities from several areas aboard the ISS at three time-points. Scientists evaluated the diversity, distribution, functional capacity, and resistance profile, using a combination of cultivation-dependent and cultivation-independent methods. Results showed that the ISS microbial communities are highly similar to those present in ground-based confined indoor environments and are subject to fluctuations. However, a core microbiome persists over time and across locations. The genomic and physiological features selected by the ISS conditions do not appear to be directly relevant to human health, although adaptations towards biofilm formation and surface interactions were observed. Therefore, results did not show a direct cause for concern about crew health, but indicated a potential threat towards spacecraft infrastructure material integrity in moist areas [1]. Some previous studies showed that S. aureus in low-shear modeled microgravity (LSMMG) conditions may not respond to environmental stresses as well as under normal gravity conditions, and the accumulated data on the impact of microgravity indicate that staphylococci display a biofilm phenotype with reduced virulence characteristics [11,39]. Further evidence that Gram-positive bacteria, Gram-negative bacteria, and yeasts are less virulent than controls when grown under microgravity conditions has emerged from comprehensive studies of the capacity of Listeria monocytogenes, methicillin-resistant S. aureus (MRSA), Enterococcus faecalis, and Candida albicans to kill Caenorhabditis elegans nematodes at the larval and adult stages on the ISS and under clinorotation [40]. In a study by O'Rourke et al. (2020) genomes of the opportunistic pathogens Burkholderia cepacia and Burkholderia contaminans (genomovars of the B. cepacia complex), which are frequently cultured from the potable water dispenser (PWD) of the ISS were sequenced and phenotypic assays to characterize these Burkholderia isolates were conducted. Results showed that all ISS-derived isolates exhibited antibiotic sensitivity similar to that of the terrestrial reference strains, and minimal differences between isolates were observed. With a few exceptions, biofilm formation rates were generally consistent across each genomovar. Overall, O'Rourke et al. (2020) concluded that while the populations of Burkholderia present in the ISS PWS each maintained virulence, they probably were not more virulent than those that might be encountered on Earth and were found to be susceptible to clinically used antibiotics [41].

Nevertheless, some studies (Section 2.3) have shown the contrary, that the virulence of some bacteria, as well as antibiotic resistance, can be enhanced in space conditions. Therefore, for now, some inconsistency regarding biofilm-forming microbial isolates and their possible impact on human health in space conditions exists. The potential impact of the development of diverse microbial populations is unclear. Although some studies indicate that biofilms pose a more significant threat as biodestructors of abiotic surfaces of different spacecraft equipment rather than a health-threat for the space crew, this potential problem should not be ruled out and should be studied in more detail.

\subsection{Microbial Biofilm Damage and Corrosion of Indoor Spacecraft Equipment}

Microbial contamination of the indoor surfaces of spacecraft may damage materials and decrease the efficiency of equipment $[3,14]$. Onboard the Salyut 6 spacecraft, biofilms were found on the piping and equipment behind panels. On Salyut 7, electrical connectors, the thermal control system's radiator, the water recycling system, and the rubber of hatch locks were found to be contaminated by microbial biofilms. On the Mir station, biofilms affected the navigation window, air conditioning, oxygen electrolysis block, water recycling unit, suit headphones, and the thermal control system $[3,4,11,13]$. The main effect of the 
destruction of a navigation window onboard Mir was attributed to Bacillus polymira, Penicillium rubens, and Aspergillus sp. $[3,13]$. A study of microorganisms in the Russian Mir space station revealed 234 different species of bacteria and fungi. Most of the isolated fungi were potential biodestructors of polymers and thus presented a potential hazard to structural materials and components of several spacecraft systems [3]. Most of the organisms in the ISS water supplies were reported to belong to Gram-negative Proteobacteria, such as Methylobacterium, Sphingomonas, Ralstonia, and Pseudomonas [42-44]. Novikova et al. (2006) performed a six-year study aiming to characterize the microbiome present onboard the ISS. They found that bacterial concentrations of up to $1 \times 10^{2} \mathrm{CFU} \times \mathrm{mL}^{-1}$ were found in potable water, with Sphingomonas sp. and Methylobacterium sp. being the dominant genera. Samples collected from surfaces showed Staphylococcus sp. to be the predominant bacteria. Airborne bacteria were also quantified, with Staphylococcus sp. again being the dominant genus.

Organic acids synthesized by microorganisms can degrade metallic surfaces, which can lead to hardware malfunctioning and short circuits [8]. Further studies emphasized that spacecraft planktonic and biofilm microbial diversity is strongly influenced by human skin-associated microbes [1-3]. The latter has also been confirmed by a metagenome profile study [33]. On the ISS, biofilms were also detected on rubber seals, viewing windows, and on different hardware surfaces [14], with a variety of pathogens isolated from the ISS forming robust biofilms. Most biofilm formers were staphylococci and enterococci $[4,14]$.

\subsection{Biofilm Formation Investigation during Spaceflight under Assessed Conditions}

Interestingly, some investigations have revealed that bacterial growth, biofilm formation, and even virulence can be enhanced under spaceflight conditions [3,45-47]. Several studies have shown that biofilms actually grow and accumulate more in space than on Earth. They form faster and therefore become resistant to antibiotics more quickly, and they make thicker structures and have different forms [5-7]. To date, only a few investigations have been conducted in space to evaluate biofilm formation. One of the first experiments was done using B. cepacia [48] as a model organism, which was previously isolated from the water system of Space Shuttle STS-81 (using the European Space Agency's PHORBOL cassette hardware onboard the Space Shuttle STS-81 mission). Samples of isolated B. cepacia were grown in conditions simulating untreated water, wastewater, and disinfected potable water. To simulate these conditions, sterile reagent grade water, tryptic soy broth (TSB), and iodine solution were used, respectively. The results showed that the spaceflight water-grown bacteria had a biofilm plate count $\left(\mathrm{CFU} \times \mathrm{mL}^{-1}\right)$ five times higher than controls on Earth. On the other hand, the spaceflight TSB-grown culture biofilm population was one-quarter of the ground controls. Analyses of the waterand iodine-grown planktonic bacteria showed a 3.5- and 2-fold increase in CFU $\times \mathrm{mL}^{-1}$ with respect to matched ground controls. Pyle et al. (1999) concluded that spaceflight enhanced bacterial growth and diminished disinfectant sensitivity in some conditions [48].

McLean and colleagues (2001) studied Pseudomonas aeruginosa biofilm formation under microgravity conditions [49]. Type III Osmotic Dewatering hardware was used for the evaluation. Cultures of P. aeruginosa were exposed to $0.2-\mu \mathrm{m}$ polycarbonate membranes, allowing them to form biofilms for either one or eight days. Post-flight confocal laser scanning microscopy revealed that the biofilms formed during the spaceflight had no morphological differences compared to ground samples. However, spaceflight had experimentation limitations: the experiment consisted of four spaceflight cultures, but only two were used for microscopic analysis [49].

Another spaceflight biofilm formation investigation was conducted by Kim et al. (2013). The investigation consisted of two experiments, which were done using BioServe Space Technologies' Fluid Processing Apparatus (FPA) during the STS-132 and -135 missions. The experiments assessed the impact of phosphate, carbon source, bacterial motility, and oxygen availability on biofilm formation of three P. aeruginosa strains in space. It was concluded that the number of viable cells, biomass and mean biofilm thickness was increased in space, regardless of phosphate concentration or carbon source. 
Moreover, interestingly, P. aeruginosa biofilms formed in space exhibited a "column-and-canopy" structure, as opposed to the flat structures observed on the ground controls $[5,6]$.

Furthermore, it was determined that Escherichia coli cells grown under low shear microgravity conditions showed increased resistance to general stress in exponential and stationary growth phases [50]. Salmonella typhimurium grown aboard the Space Shuttle mission STS-115 showed increased virulence under low shear microgravity conditions, compared to the same strain grown on Earth [51].

Aunins et al. (2018) studied the effect of microgravity on E. coli by analyzing the transcriptomic response of these bacteria grown on the ISS. Studied bacteria were grown in increasing gentamicin concentrations. In two days, E. coli grown in space, compared with the Earth control, adapted to higher gentamicin concentrations. Moreover, the strain on the ISS showed upregulation of 50 stress response genes, suggesting that microgravity induces stress responses associated with antibiotic stress and likely increases antibiotic tolerance in bacteria in space [3,11,52]. Indeed, in bacteria isolated from the ISS, increased resistance to antibiotics has often been reported. E. faecalis and Staphylococcus spp. isolates from the ISS have also been shown to harbor plasmid-encoded transfer genes, which facilitate the dissemination of antibiotic resistance. Therefore, these findings regarding ISS pathogens once again illustrates the necessity for novel, safe biofilm-combating or strongly biofilm-reducing approaches which can be easily used on the ISS and other spacecraft [3,11].

\subsection{Biofilm Control Methods}

Over the last few decades, the search for and analysis of bacterial biofilm inhibition and control methods have begun to develop rapidly in order to discover the best option for their removal. To date, a wide range of research articles regarding bacterial biofilm control methods are available. Therefore, to summarize them, we performed an analysis of biofilm research performed during the last two years (August 2018-August 2020). To evaluate the prevalence of biofilm control/inhibition methods used for the past two years, the PubMed (NCBI) (https:/www.ncbi.nlm.nih.gov/pubmed/) database was chosen for the analysis, as it is one of the most comprehensive. In order not to exclude search results that could be significant for the investigation, a general search term (keyword) "biofilm" was used. According to the scientific articles found in the PubMed database regarding biofilm inhibition and control, all methods, based on their nature, can be divided into six groups: (1) natural (biological) [53-55]; (2) chemical [56-58]; (3) physical [59,60]; (4) physicochemical [61-63]; (5) physical in combination with natural [64], and (6) natural in combination with chemical [65]. A summary of the bacterial biofilm inhibition/control methods described in the past two years is shown in Figure 1.

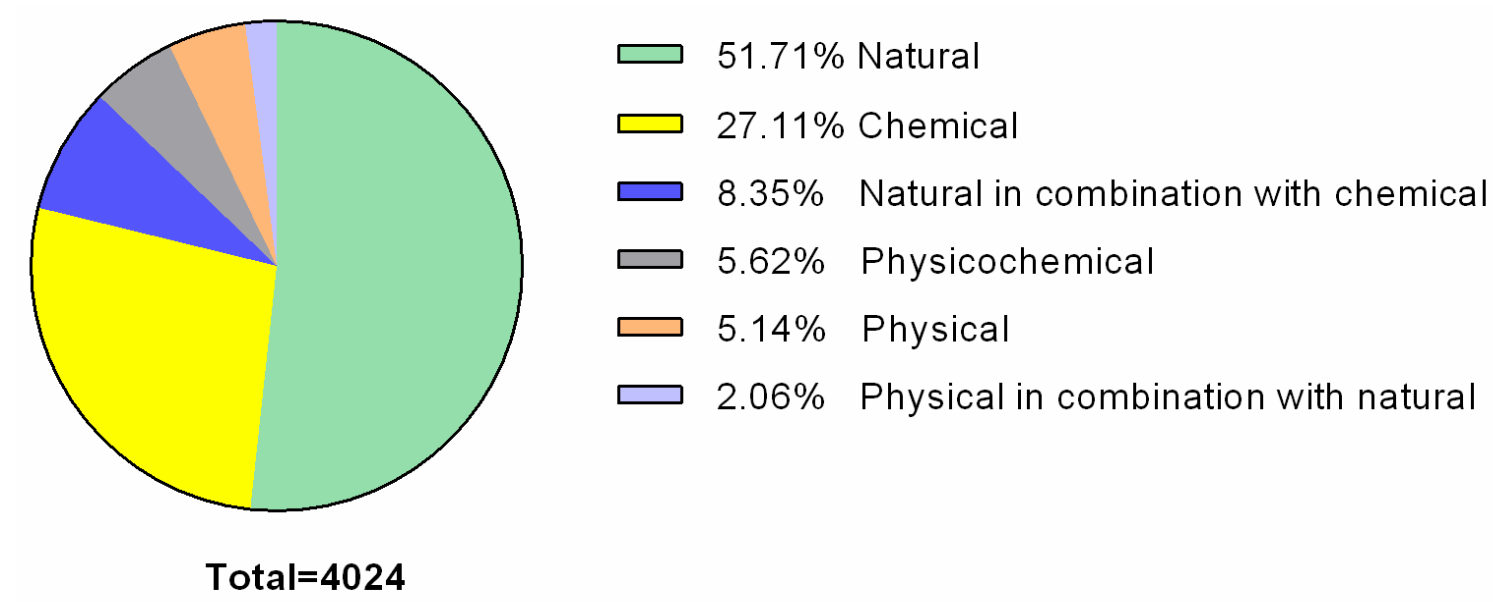

Figure 1. Summary of bacterial biofilm inhibition/control methods described during the last two years (2018-2020). PubMed total search results using “biofilm" as a keyword consisted of 15,315 entries, of which 4024 entries corresponded to articles regarding bacterial biofilm inhibition/control methods. 
To date, only a few methods have been tested in order to find a suitable way to control microbial biofilm formation in space. In the majority of cases, these methods were tested on biofilms that were grown artificially in space conditions, subjected to real spaceflight conditions in a pre-formed state, or bacteria that could presumably form biofilms were isolated from areas such as potable water systems on spacecraft.

In 2010, Wong et al. tested disinfectants such as hydrogen peroxide $\left(\mathrm{H}_{2} \mathrm{O}_{2}\right)$, colloidal silver, and buffered $\mathrm{pH}$ solutions on bacteria isolated from ISS water systems: Ralstonia picketti, Burkholderia multivorans, Caulobacter vibrioides and Cupriavidus pauculus. Results of the experiments showed that a single flush with either $6 \% \mathrm{H}_{2} \mathrm{O}_{2}$ or a mixture of $3 \% \mathrm{H}_{2} \mathrm{O}_{2}$ and $400 \mathrm{ppb}$ colloidal silver solution effectively reduced bacterial concentrations for up to three months [9].

Perrin et al. (2018) performed a long-lasting VIABLE experiment (involving the evaluation and monitoring of microbial biofilms inside the International Space Station) that aimed to evaluate bacterial contamination on different spacecraft material surfaces [30]. These surfaces were subjected to varying pre-treatments with compounds such as biosurfactants, hydrogen peroxide, silica, and silver coating. Total bacterial load and the taxonomic composition of the microorganisms were evaluated by ATP-metry, qPCR, and 16S rRNA amplicon sequencing, respectively. The results of the study showed that the bacterial load on the studied surfaces was low and did not exceed the values allowed on the ISS. Taxonomic composition was detected to be similar to that found previously (Enterobacteriales, Bacillales, Lactobacillales, etc.) [30]. Finally, Perrin et al. (2018) concluded that no material or pre-treatment of the material used was shown to be better than any other, nor did it affect the quantity and taxonomy of the microbial contamination of ISS [30].

In 2018, Zea et al. began an extensive study aiming to design a spacecraft biofilm formation experiment with P. aeruginosa and Penicillum rubens as model microorganisms [3]. These microorganisms were planned to be cultured on different materials such as cellulose membrane, aluminium 6061, titanium Ti-6AL-4V, polycarbonate, quartz, silicon, stainless steel 316, carbon fiber, and lubricant-impregnated coupons using different nanotopographies to evaluate the changes in formed biofilm mass, thickness, morphology, and gene expression, and thus find the best antibacterial surfaces. However, so far, only the results of preliminary space-based testing to inform the spaceflight experiment design have been presented by the authors.

A more recent investigation revealed that bacteria such as Cupriavidus metallidurans, Chryseobacterium gleum, Ralstonia insidiosa, R. pickettii, Methylorubrum (Methylobacterium) populi, and S. paucimobilis, which were isolated from the ISS portable water system and presumably formed biofilms in spacecraft, are affected by bacteriophages and multiple predatory bacteria. The latter were tested in order to remove individual members of the biofilm in situ. However, the combination of precise and substantial depletion of a single target species was not achieved [10].

Sobisch et al. (2019) investigated the antimicrobial activity of AGXX ${ }^{\circledR}$, a novel surface coating consisting of micro-galvanic elements of silver and ruthenium, along with examining the activity of a conventional silver coating. The antimicrobial materials were exposed on the ISS for 6, 12, and 19 months each, at a place frequently visited by the crew. The conventional Ag coating showed little antimicrobial activity. Microbial diversity increased with increasing exposure time on all three materials. After six months' exposure on the ISS, no bacteria were recovered from AGXX ${ }^{\circledR}$, after 12 months nine cultures were isolated, and after 19 months three cultures were isolated [4]. AGXX ${ }^{\circledR}$ coating was previously invented and patented. This invention relates to the production and use of novel bioactive devices and metallic coatings, e.g., for sterilizing, disinfecting, and decontaminating water or aqueous solutions [66].

\section{Antimicrobial Photoinactivation}

Antibiotic resistance by bacterial biofilms is an enormous problem in the world. Therefore, the development of alternative technologies could help to solve this problem. One of the promising approaches to controlling biofilms is the use of antimicrobial photoinactivation (API) (referred to as photodynamic therapy (PDT) when treating infectious disease or cancer). API is used not only to treat 
microbial infections but also to control the growth of microorganisms on various surfaces $[67,68]$. In this context, non-thermal and non-chemical API based on natural photosensitizers (PSs) might serve as a promising bacterial biofilm-and planktonic cell-decontamination tool in spacecraft. API is a modern biophotonic technology based on the interaction of a non-toxic PS, molecular oxygen, and low doses of harmless light of a suitable wavelength to match the PS absorption region [69]. Usually, the illuminated ground state (single-state) PS (1PS), located in the bacterial cells or at the bacterial cell surface, absorbs the light and is excited to its short-lived (nsec) singlet state, 1PS* (Figure 2). The excited-state electrons undergo intersystem crossing to a lower energy but longer-lived ( $\mu \mathrm{sec}$ ) PS triplet-state (3PS*) or return to the ground state by fluorescence emission and/or heat emission. The triplet-state PS interacts with molecular oxygen, electron donors or acceptors, and can produce reactive oxygen species (ROS). The different ROS generated by API mechanisms (upon photoinactivation) can migrate away from the formation site, destroy extracellular polysaccharides, and attack adjacent targets, including proteins, lipids, and nucleic acids present within the biofilm matrix, on the cell surface, and inside the microbial cells. Oxidation of sensitive biomacromolecules (proteins, DNA, RNA, lipids, etc.) initiates various forms of cellular damage and destroys bacterial cells in different growth modes (Figure 2) [70-72].



Figure 2. Schematic illustration of antimicrobial photoinactivation (API) mechanism (Jablonski diagram).

As shown in Figure 2, the photochemical reactions can be realized via a Type I or Type II mechanism and require proximity between the PS triplet state and the substrate. Both types of ROS can damage biomolecules and destroy or kill all known classes of pathogenic microorganisms. Type I reactions generate radicals following triplet state electron transfer from the PS triplet state to a substrate. A common terminal substrate for Type I reactions is molecular oxygen, leading to the production of radicals, such as superoxide anion $\left(\mathrm{O}_{2} \bullet-\right)$, hydrogen peroxide $\left(\mathrm{H}_{2} \mathrm{O}_{2}\right)$, hydroxyl radicals $(\mathrm{OH} \bullet)$, carbonate radical anions $\left(\mathrm{CO}_{3} \bullet-\right)$, and lipid-derived ions (LOO•), which oxidize biomolecules and cause cell damage and ultimately death [73]. In Type II mechanism reactions, the excited PS can transfer its energy directly to molecular oxygen $\left({ }^{3} \mathrm{O}_{2}\right)$ and form the highly reactive short-lived singlet oxygen $\left({ }^{1} \mathrm{O}_{2}{ }^{*}\right)$, which is a strong oxidant compared to ground state triplet oxygen [74]. Both types of reactions can occur simultaneously, but in most cases, API proceeds via a Type II reaction. All the same, the ratio between these processes still depends on the type of PS used and the microenvironment in which photosensitization is applied [75]. It is also important that the initially produced ${ }^{1} \mathrm{O}_{2}$ can subsequently react with biological substrates (such as unsaturated fatty acids) to produce secondary radicals (such as lipid peroxide radicals) [76]. It allows the achievement of a significant decrease in the population of bacteria with minimal damage or thermal effects on the surrounding matrix $[77,78]$. Furthermore, recently, some scientists have proposed another oxygen-independent photoinactivation type, which they termed the "Type III photochemical pathway" [79]. This mechanism involves a 
photoinduced electron transfer that produces reactive inorganic radicals, which might be useful to inactivate various anaerobic bacteria.

It is important to note that one of the essential advantages of API compared to other antibacterial tools is the absence of any bacterial resistance to this treatment $[74,80,81]$. According to Liu et al. (2015), this is due to several reasons [74]:

(i) The time between administration of the PS and API is too short for the pathogen to develop resistance;

(ii) The PSs exhibit no dark toxicity (or very low toxicity), as a result of which bacteria do nothave to engage adaptive survival mechanisms against the PSs;

(iii) The cells are too damaged after API, disabling them to confer cross-generation additivity;

(iv) API does not target a single site in bacteria, so the ROS generated by this treatment target various pathogen cell structures and different metabolic pathways.

Numerous investigators have demonstrated significant reductions in both Gram-positive and Gram-negative bacteria (in vitro and in vivo) after API treatment [82-85]. The antibacterial efficiency of this treatment depends on many factors, including the physiological state of the bacteria, as well as their cellular structure and organization. Desirable properties of the PSs consist of optimal photophysical properties, pure chemical composition, acceptable stability and shelf life, water-solubility, no tendency to aggregate, high triplet state formation yield, low dark toxicity, resistance to photobleaching, high phototoxicity, small size for membrane permeation, minimal side effects, the ability to accumulate in bacteria or bind to the bacterial cell envelope, a broad-spectrum of antimicrobial action at relatively low concentrations, and a low light dose [86-88].

However, to date, there is no perfect PS that meets all the above mentioned characteristics. Most studied PSs are based on tetrapyrrolic macrocycles (porphyrins), chlorines, bacteriochlorins, phthalocyanines, and texaphyrins. These molecules have low toxicity, can form long-lived triplet excited states, and have high affinity to life-essential molecules. It has been found that PSs that fulfill these requirements should have a pronounced positive (cationic) charge [89]. It is known that a fundamental difference exists in the susceptibility to photosensitization between Gram-positive and Gram-negative bacteria. It is well documented that photosensitization-based inactivation is not effective enough to kill Gram-negative bacteria when neutral or anionic PSs are used. Neutral, anionic, or cationic PSs are mostly able to inactivate Gram-positive bacteria [90]. In contrast, Gram-negative bacteria are less susceptible to this treatment, due to their more conjugate cell wall structure and additional negatively charged outer membrane. They require a higher concentration of PS and light dose [91]. It is better to use cationic PSs or supplementation of API with permeabilizing agents to achieve a significant cell death of Gram-negative bacteria [90].

There are two main routes of PS-cell interaction. In the first case, it may form a stable conjugate with the surface of the cell wall. In this way, the PS is transported inside the cell, where it associates with the key structures and irreversibly damages them after photosensitization [80]. Demidova and Hamblin (2005) raised the hypothesis that there are three groups of antimicrobial PSs-(1) tightly bound, which penetrate microorganisms; (2) loosely bound; and (3) those which do not demonstrate binding [92].

PSs used for API are classified into four groups based on their structure and origin [19]: synthetic dyes, tetrapyrrole structures, natural PSs, and nanostructures. For bacteria biofilm inactivation in spacecraft, non-toxic, ecologically friendly, chemically pure, stable, non-bleaching, easy-to-produce, and water-soluble PSs should be used. Natural PSs meet the above-listed criteria and are one of the safest options of PSs for spacecraft use that have been proposed to date. Currently, four main natural products have been used for API: curcumin, riboflavin, perylenequinones (hypericin, hypocrellin), and psoralens [89]. Furthermore, chlorophyll derivatives have been used as natural PSs [93,94]. Moreover, several studies have recently reported that natural PSs extracted from plants can also be 
effective for the API approach $[95,96]$ (see Table S1 in Supplementary Materials). Figure 3 depicts the chemical structures (2D and 3D models) of natural PSs used in API and discussed in this review.

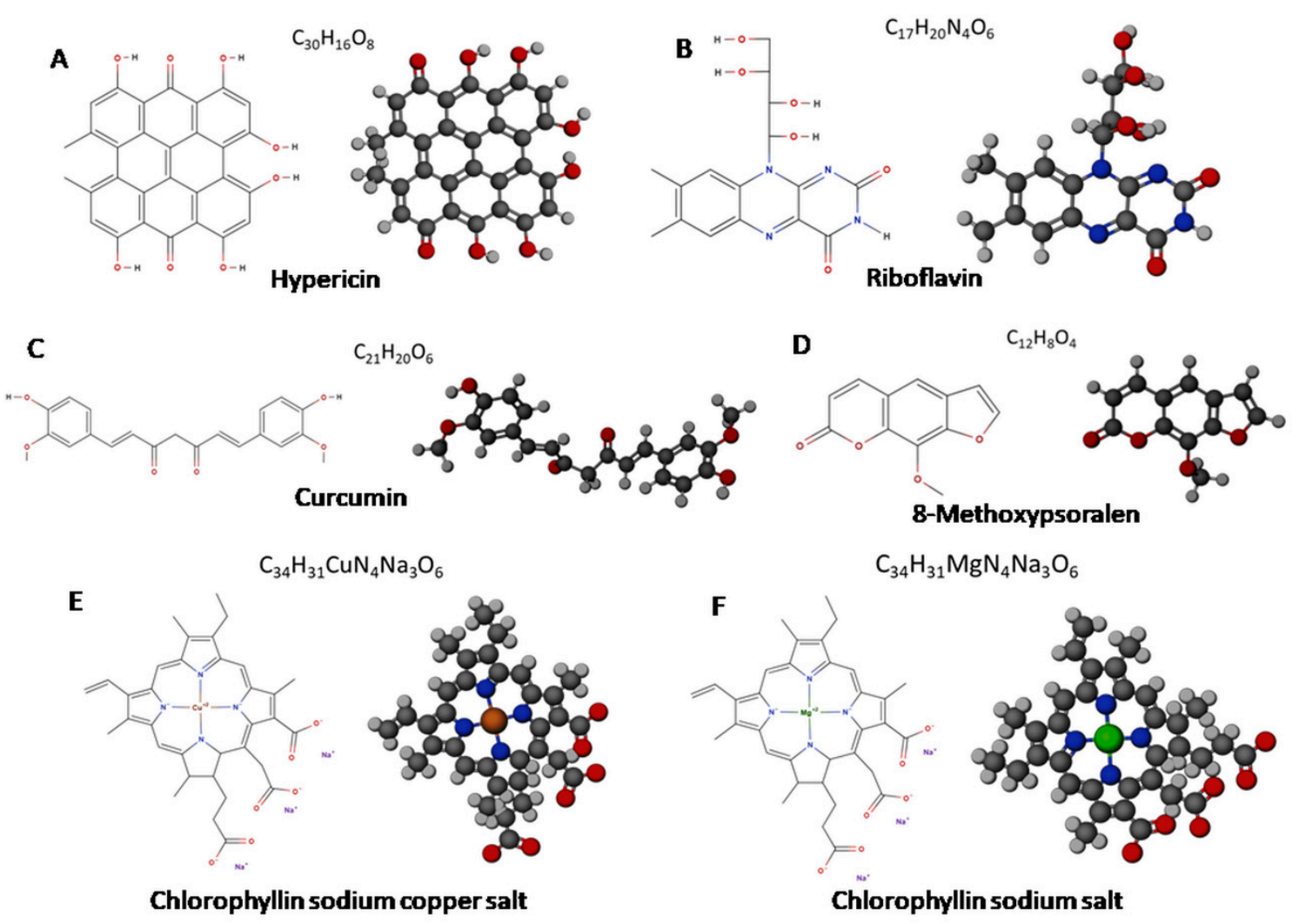

Figure 3. Chemical structure models of naturals photosensitizers (PSs) (2D and 3D).

Numerous API studies have demonstrated biofilm-eradication or substantial reduction, but few of them have used natural PSs. We thus review the recent literature concerning the efficiency of API based on natural PSs toward various bacterial species in biofilms, as well as planktonic growth modes. The review is mainly focused on biofilm-forming bacteria because this mode of growth not only poses a threat to spacecraft crew health but also damages spacecraft equipment and is difficult to eradicate from safety systems.

\subsection{Perylenequinones}

The perylenequinones are a class of natural products characterized by a pentacyclic conjugated chromophore, giving rise to photoactivity. The most commonly used natural class $B$ perylenequinone PS is hypericin (Hyp) (4,5,7,4', $5^{\prime}, 7^{\prime}$-hexahydroxy-2,2'-dimethylnaphtodiant hrone) (Figure 3A). Hyp is a naturally occurring red-colored anthraquinone derivative that comprises one of the main bioactive constituents of Hypericum perforatum (also called Saint John's Wort). Hyp, which is almost insoluble in water, disperses in an aqueous physiological environment, producing non-fluorescent high-molecular-weight aggregates [97]. Therefore, it is soluble in 100\% ethanol, methanol, or dimethyl sulfoxide (DMSO). Hyp exhibits an excitation maximum at $593 \mathrm{~nm}$ in DMSO solution and $544 \mathrm{~nm}$ in methanol [98]. As shown in Figure 4, upon light activation, at low concentrations, Hyp is efficient primarily in the generation of singlet oxygen (Type II mechanism), whereas, at high concentrations, it produces superoxide anion (Type I mechanism) [99]. 

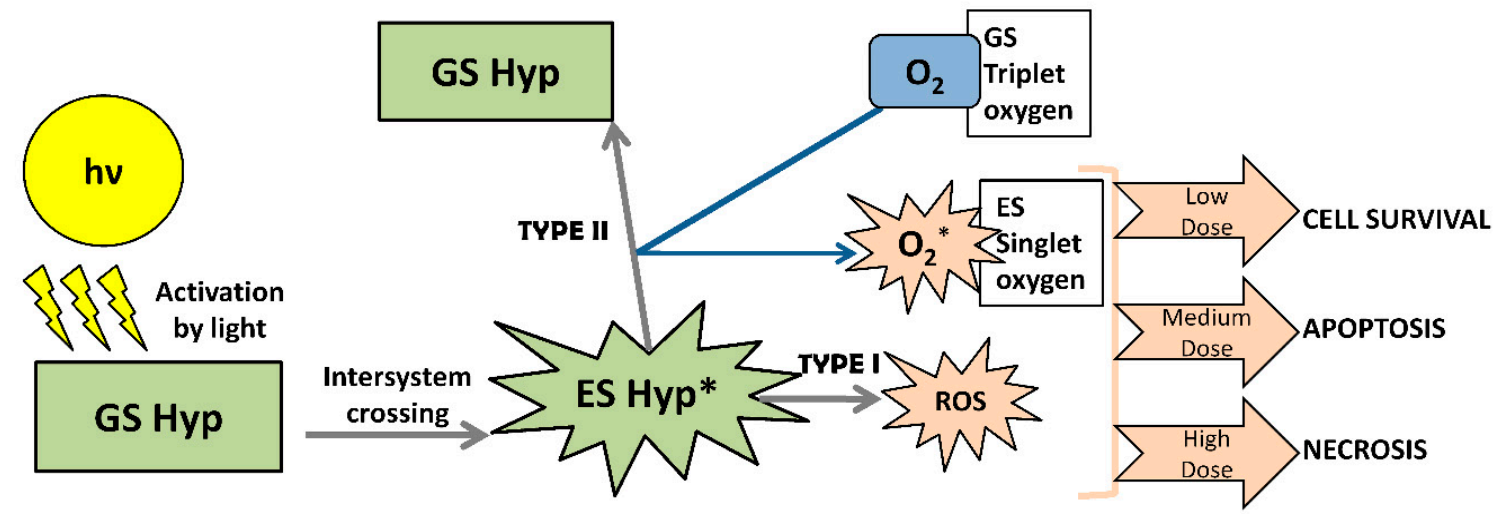

Figure 4. Schematic representation of the mechanism of Hyp photoactivation and induced damage; GS: ground state, ES: excited state.

Hyp (or its derivatives)-based API can induce death of Gram-positive methicillin-susceptible S. aureus (MSSA) and MRSA cells [100-110]. Hyp-mediated photoinactivation is reported to be more effective against planktonic $S$. aureus than against its biofilms [105-107]. The latter could be explained by the presence of polysaccharide intercellular adhesin (PIA) in the biofilm that blocks the uptake of hydrophobic Hyp. An excellent method to improve the effect of API is a chemical perturbation of the biofilm, for example, with acetylcysteine. Kashef et al. (2015) demonstrated that the combined use of Hyp and acetylcysteine increased the intracellular delivery of Hyp in S. aureus [107]. It has also been shown that Hyp-mediated API renders other Gram-positive bacteria including Streptococcus mutans and Streptococcus sobrinus [111], L. monocytogenes [112], B. cereus [113], E. faecalis [106] inactive.

It is known that Hyp is a neutral hydrophobic PS. Therefore, it does not simply get into Gram-negative bacteria such as E. coli [106,108,110,114,115], P. aeruginosa [100,106], and Salmonella enterica [112]. De Melo et al. (2013) used electroporation to increase the uptake of Hyp, thus enhancing the inactivation of E. coli to 3.5 logs [108]. Kairyte et al. (2012) combined Hyp-based API with high-power pulsed light treatment and increased the reduction of S. enterica from 1 to $6.7 \log$ [112].

The fungal metabolites hypocrellin A (HA) and hypocrellin B (HB) are isolated from the parasitic fungi Hypocrella bambusae Sacc and Shiraia bambusicola P. Henn, respectively, which are found in different areas of Asia [88]. HB is known as a PS with high quantum yields of ${ }^{1} \mathrm{O}_{2}$, low dark toxicity, a quick clearance rate, and availability in a pure monomeric form [116]. Jiang et al. (2013) used HB for the photoinactivation of Gram-positive S. aureus [117] and Gram-negative E. coli [118]. Otieno et al. (2020) found that $100 \mu \mathrm{M}$ of $\mathrm{HB}$ in the presence of $72 \mathrm{~J} / \mathrm{cm}^{2}$ light irradiation could obtain $\sim 7 \mathrm{log}$ reductions of S. aureus, E. faecalis, and Streptococcus pneumoniae. On the contrary, HB-based API efficacy on Gram-negative E. coli and Klebsiella pneumoniae were much lower. Gram-positive bacteria biofilms were also susceptible to API, but the efficiency was lower than that of planktonic cells [119]. Su et al. (2011) found that HA had API activity against Gram-positive S. aureus and Bacillus subtilis, and also against Gram-negative E. coli and S. Typhimurium when $\mathrm{CaCl}_{2}$ or $\mathrm{MgCl}_{2}$ was employed to weaken the permeability barrier [120].

In addition to the described bactericidal effects of Hyp [105,106], in vitro fungicidal [121,122] effects have also been reported. Light-activated Hyp is also considered to be an effective antiviral agent $[123,124]$. However, some clinical studies have revealed that high doses of Hyp can induce phototoxic skin reactions without showing any detectable antiviral or antiretroviral activity in patients with viral infections $[125,126]$. Hyp also possesses various positive or negative biological activities without light activation [127]. Therefore, for spacecraft biofilm decontamination applications, Hyp concentrations should be considered. Spacecraft surface API decontamination using Hyp could be potentially carried out, but for safety reasons, crewmembers' exposure to it should be avoided during the process. 


\subsection{Riboflavin}

Riboflavin (RF) (Figure 3B), also known as vitamin $\mathrm{B}_{2}$, is an essential micronutrient, which exhibits excellent photosensitive characteristics, plays a vital role in cell metabolism processes, and can be considered safe when administered to humans $[128,129]$. It is the main component of the cofactors flavin adenine dinucleotide (FAD) and flavin mononucleotide (FMN) in many flavoproteins and is ubiquitous among plants and animals $[88,128]$. RF is non-toxic and is labeled as "Generally Recognized As Safe" (GRAS) for consumption by the US Food and Drug Administration (FDA).

$\mathrm{RF}$ crystals have a yellow-orange color, whereas neutral solutions of RF have a green color. This is why they are used as food colorant known as E101. RF is one of the most widely studied compounds in terms of photostability and degradation in aqueous and organic solvents. RF in organic solvents shows strong absorption in the region of 270-271; 344-358 and 440-450 nm [130]. RF exhibits absorption maxima at 223, 267, 373, and $444 \mathrm{~nm}$ in the UV and visible regions in aqueous solution. It is degraded on exposure to light into various photoproducts: formylmethylflavin (FMF), lumichrome (LC), lumiflavin (LF), carboxymethylflavin (CMF), 2,3-butanedione, a $\beta$-keto acid, and a diketo compound [131]. The kinds of photoproducts formed by RF depend on the solvent, $\mathrm{pH}$, buffer type, concentration, oxygen content, light intensity, and wavelengths.

RF has been generally known to have antimicrobial properties. Therefore, light-induced activation of RF can selectively damage pathogens [132]. RF generates ROS such as superoxide radicals, hydroxyl radicals, hydrogen peroxide, and singlet oxygen when exposed to visible or UV light in the presence of oxygen $[129,133]$. The photooxidation of RF (Figure 5) includes either an electron transfer, which generates a superoxide ion and RF free radical species (Type I), or an energy transfer that causes the formation of singlet oxygen (Type II) [134]. The type I mechanism occurs preferentially at low oxygen concentrations [135].

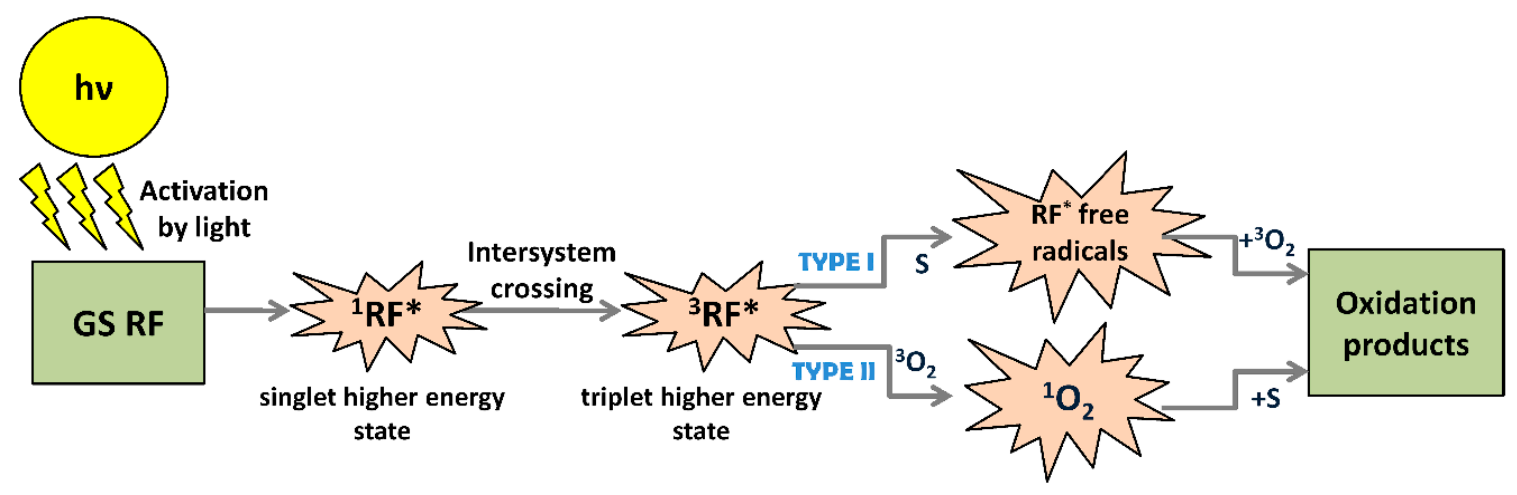

Figure 5. Photosensitized RF-mediated oxidation mechanisms. Upon activation by light, RF is excited to a singlet state of higher energy $\left(1 \mathrm{RF}^{*}\right)$, followed by intersystem crossing to an excited triplet state $\left(3 R F^{*}\right) .3 R F^{*}$ can be involved in a photosensitized oxidation process of Type I or Type II. In the Type I mechanism, RF transfers the energy to a substrate $(S)$ and generates $\mathrm{RF}^{*}$ free radical species that interact with molecular oxygen in the ground state to yield oxidation products. In the Type II mechanism, RF transfers the energy to molecular oxygen in the ground state to generate the more reactive singlet molecular oxygen $\left({ }^{1} \mathrm{O}_{2}\right)$. The latter, in reaction with $\mathrm{S}$, leads to the final oxidation products (according to [135]).

It was found that RF, owing to its antimicrobial properties, can be applied to blood product sterilization and to a photocrosslinking procedure designed to stiffen the human cornea in patients with keratoconus [136,137]. Halili et al. (2016) found that $0.1 \%$ RF in the presence of $5.4 \mathrm{~J} / \mathrm{cm}^{2} \mathrm{UV}$ light $(375 \mathrm{~nm})$ irradiation could obtain a 98\% reduction of Gram-positive S. aureus [138], whereas O'Rourke and Dowds (1992) showed the killing of B. subtilis [139]. However, Kashiwabuchi et al. (2012) failed to show any killing of $S$. aureus after RF-based API in the same treatment conditions [140]. A study by Makdoumi et al. (2010) resulted in the significant inactivation of various antibiotic-resistant bacteria 
(Staphylococcus epidermidis, S. aureus, P. aeruginosa, E. faecalis) mediated by RF photoactivated using UVA $(365 \mathrm{~nm})$ [141-143] and blue light (412 nm and $450 \mathrm{~nm})$ [144,145] in thin layers of fluid $(0.4-1.76 \mathrm{~mm})$.

The antimicrobial efficacy of RF-based API was also presented by Maisch et al. (2014), who used cationic RF derivatives FLASH-01a and FLASH-07a for photoinactivation of S. aureus, P. aeruginosa, E. coli, and Acinetobacter baumannii. It was shown that the use of these PSs after light irradiation resulted in 6.6-6.7 log reductions in the viable counts of the bacteria [146].

Although RF belongs to the group of water-soluble vitamins, it is in fact one of the least soluble in water $(0.10-0.13 \mathrm{~g} / \mathrm{L})$ [147]. FMN, which is produced from phosphorylation at the 50-position of the ribityl side-chain of RF, is also very sensitive to light. The water solubility of FMN is 200 times better than that of RF. Thakuri et al. (2011) obtained the killing of S. aureus and P. aeruginosa when FMN was excited by blue light [148], whereas Liang et al. (2015) also showed the significant killing of E. coli [149]. However, as was demonstrated by Wong et al. (2017), FMN photochemical treatment of S. aureus using a blue LED required a longer irradiation time than when using violet light [150].

\subsection{Curcumin}

Curcumin (CUR) is a natural yellow pigment extracted from the rhizomes of Curcuma longa that has been widely used as a foodstuff and as a spice. Since it is a foodstuff, it has attracted attention as a possible natural and non-toxic antimicrobial PS, particularly in dental applications. CUR is a relatively hydrophobic polyphenolic compound that is readily soluble in organic solvents (Figure 3C). It absorbs visible light in the 405-435-nm range, depending on the solvent [151]. Despite CUR's widespread use as a PS in API, the mechanisms of its phototoxicity are not completely understood. Both Type I and II reactions are characteristic of CUR. It shows oxygen-dependent phototoxicity but is also known to be an antioxidant [152].

Several studies have verified its photoinactivation ability when activated with the proper wavelengths of light [88]. CUR-based API could induce significant killing of Gram-positive E. faecalis cells [153-156]. Pileggi et al. (2013) demonstrated that $10 \mu \mathrm{M}$ of photoactivated CUR could completely inactivate E. faecalis biofilms after $30 \mathrm{~min}$ preincubation and 240-sec irradiation [156]. Meanwhile, Manoil et al. (2014) found that blue light-activated CUR can inactivate planktonic S. mutans, but the effect on biofilm was only 44\% [157]. Paschoal et al. (2015) demonstrated that CUR could completely photoinactivate S.mutans by $5.97 \operatorname{logs}$ when exposed to a blue LED light for $4 \min (\lambda=420 \pm 20 \mathrm{~nm})$ [158]. Therefore, a solution of CUR produced a 5.3-log reduction of a planktonic $S$. mutans suspension after 5 min irradiation with $450 \mathrm{~nm}$ light [159]. Araújo et al. (2017) showed that photoactivated CUR could kill cariogenic bacteria in vitro [160].

CUR-based API of Gram-negative bacteria is less studied. Penha et al. (2017) determined that photodynamic inactivation of Gram-negative bacteria (E. coli, S. enterica, P. aeruginosa) mediated by $75 \mu \mathrm{M}$ CUR and $470 \mathrm{~nm}$ light was insignificant [161]. Haukvik et al. (2009) failed to show 100\% killing of E. coli after CUR-based API at $430 \mathrm{~nm}$ (light dose $30 \mathrm{~J} / \mathrm{cm}^{2}$ ) in the same treatment conditions [155].

\subsection{Psoralens}

Psoralens are coumarins that possess a furan ring, which is why they are also called furanocoumarins (Figure 3D). Psoralens are commonly found in Rutaceae (Ruta graveolens) and Umbelliferaceae (Apium graveolens, Angelica archangelic, Petroselenium crispum) plants [162]. Psoralens are commercially derived from Ammi majus, a plant found in Egypt. Most psoralens have strong absorption bands in the range of $200-350 \mathrm{~nm}$. Upon illumination with UVA/Vis light, psoralen molecules may undergo several reactions: Type I (electron transfer mechanism), Type II (electron-exchange type mechanism), Type III (photobinding to, e.g., DNA) [163]. The combination of 8-methoxypsoralen with UVA light (known as PUVA) was first introduced as a medical treatment for psoriasis [89]. PUVA has been used for the inactivation of bacteria, viruses, and protozoa in platelet and plasma blood components. However, now psoralens are not commonly used for human treatment, largely because of concerns over the long-term safety of ultraviolet light therapy and the toxic effects of psoralens 
administered orally [164]. Harding and Schwab (2012) used lime extract and synthetic psoralens to perform E. coli photoinactivation with UV radiation. It is believed that they may serve as enhancers of solar disinfection of water [165]. Because of the possible toxicity of psoralens, its usage for API in spacecraft for the decontamination of biofilms should be cautious, ensuring crewmembers are not exposed to this PS during the decontamination process.

\subsection{Chlorophyllin}

Although chlorophyll exhibits tetrapyrrole structures, as the most widespread phytochemical pigment in higher plants, algae and bacteria, it could also be relevant to the development of natural PSs. Chlorophyll and its derivatives have been identified as potential anti-mutagens and maybe chain-breaking antioxidants by acting as effective electron donors [166]. Chlorophyll derivatives exert strong photodynamic properties without the formation of toxic by-products [167].

Natural chlorophyll derivatives are widely used as PSs in photodynamic therapy. Various chlorophyll preparations are used in the industry as food colorants to reinforce or give a green color to manufactured products [168]. The chlorophyll molecule contains a cyclic tetrapyrrole nucleus with a coordinated magnesium atom at the center and a long hydrocarbon side chain attached through a carboxylic acid group [169]. Chlorophyll is a chlorin pigment, which is produced through the same metabolic pathway as other porphyrin pigments such as heme. Natural chlorophylls are so unstable that in most of the research, their semi-synthetic derivatives have been used as models for several experimental designs [170]. Chemical transformation of lipophilic chlorophylls into a freely water-soluble sodium salt derivative involves the removal of the phyttyl tail and the additional replacement of the central coordinated $\mathrm{Mg}^{2+}$ with $\mathrm{Cu}^{2+}$ (Figure 3E) [171]. The first type of these compounds is a sample called sodium chlorophyllin (Chl), whereas the second one is known as chlorophyllin sodium copper salt (CuChlNa). Chlorophyllins can be simply extracted from different plant sources such as spinach, grass, dandelion, green cabbage, water hyacinth, and algae $[94,172]$. CuChlNa is a water-soluble food colorant (E-140ii) and is widely used in dietary supplements and cosmetics [173,174].

$\mathrm{Chl}$ is obtained by saponification of the solvent-extracted products from edible plant material, grass, lucerne, and nettles [168]. It contains water-soluble chlorophyll derivatives and is marketed as a grey-green powder after dehydration of the chemical preparation [174]. It should be noted that $\mathrm{Chl}$ is efficient primarily in the generation of singlet oxygen (Type II mechanism). Moreover, the expression of genes (OxyR, AhpC, GrxA, SulA, AtpC, groEL, STM0225) after API confirmed that treated cells of bacteria survived oxidative stress induced by emerging ROS. Eventually, it was found that API induces significant cell membrane disintegration, which enables extensive leakage of DNA and protein components and causes shrinkage of cells [175].

Chl preferentially associates with microorganisms and, after activation with visible light of an appropriate wavelength, generates ROS, which induce lethal damage of bacteria. Several studies have verified Chl's photodynamic killing ability of Gram-positive bacteria when PS-activated with the proper wavelengths of light. Kreitner et al. (2001) studied inactivation of agar-plated Gram-positive S. aureus, B. cereus, and B. subtilis by $10^{-5} \mathrm{MChl}$-based API [176]. Luksiene et al. $(2013,2010,2011)$ used $10^{-8}-10^{-7} \mathrm{M}$ $\mathrm{Chl}$ and $405 \mathrm{~nm}$ light and achieved complete photoinactivation of Gram-positive L. monocytogenes and B. cereus in phosphate buffered saline (PBS) buffer [177-179]. However, the Chl-based API effect is lower against Gram-negative bacteria such as E. coli and S. enterica $[175,177,180,181]$. To increase the susceptibility of Gram-negative bacteria to Chl-based API, Chl-chitosan conjugate [175,181], high power pulsed light [175], porphyrin precursor ALA [177], or lower dose antibiotics could be used [182].

To conclude this Section, most of the currently accepted API methods are applied in the medical area. In recent decades, API was used for the treatment of various microbial infections and to control the growth of microorganisms on various surfaces $[80,183]$. Several papers have also been published on the photodynamic inactivation of microorganisms regarding food surface decontamination. API can be used for cleaning and sanitation of food-processing and food-handling surfaces as well [80]. Berg et al. (2014) patented a microbial growth controlling method based on surface treatment with 
one or more photosensitizers and further exposure to electromagnetic radiation [67]. Luksiene and Buchovec (2009) patented a method of food and food-related surface decontamination using non-thermal irradiation and food-friendly PSs [68]. The effective photoinactivation of different physiological forms of bacteria obtained in vitro and on various surfaces looks promising and may serve as a background for the further development of a novel, safe, hurdle technology for the decontamination of confined spacecraft systems. In food and medical settings PSs are usually sprayed, spread, and infused onto surfaces, or sometimes incorporated into them [184,185]. For spacecraft biofilm decontamination applications, PSs can be applied analogically_by spraying, spreading, and/or infusing them onto surfaces, as is done on Earth. Nevertheless, in order to enable safe and effective API applications in spacecraft, suitable concentrations of PSs and specific light doses must be optimized. Optimal API conditions should be studied on Earth in advance in simulated space conditions.

\section{Illumination Requirements for API}

An indispensable part of API and PDT is proper illumination. The operational mechanism of API requires the presence of light in order to excite internal electrons into excited states (Figure 2). In particular, a proper spectrum and sufficient amount of excitation (dose) have to be provided for the desirable inactivation effect. In general, one has to illuminate the PSs with light of a photon-energy greater or equal to the energy distance between the ground state $\mathrm{PS}_{0}$ and excited state 1PS*. Still, the absorption curves of certain PSs are the most accurate characteristics to follow (Figure 6).

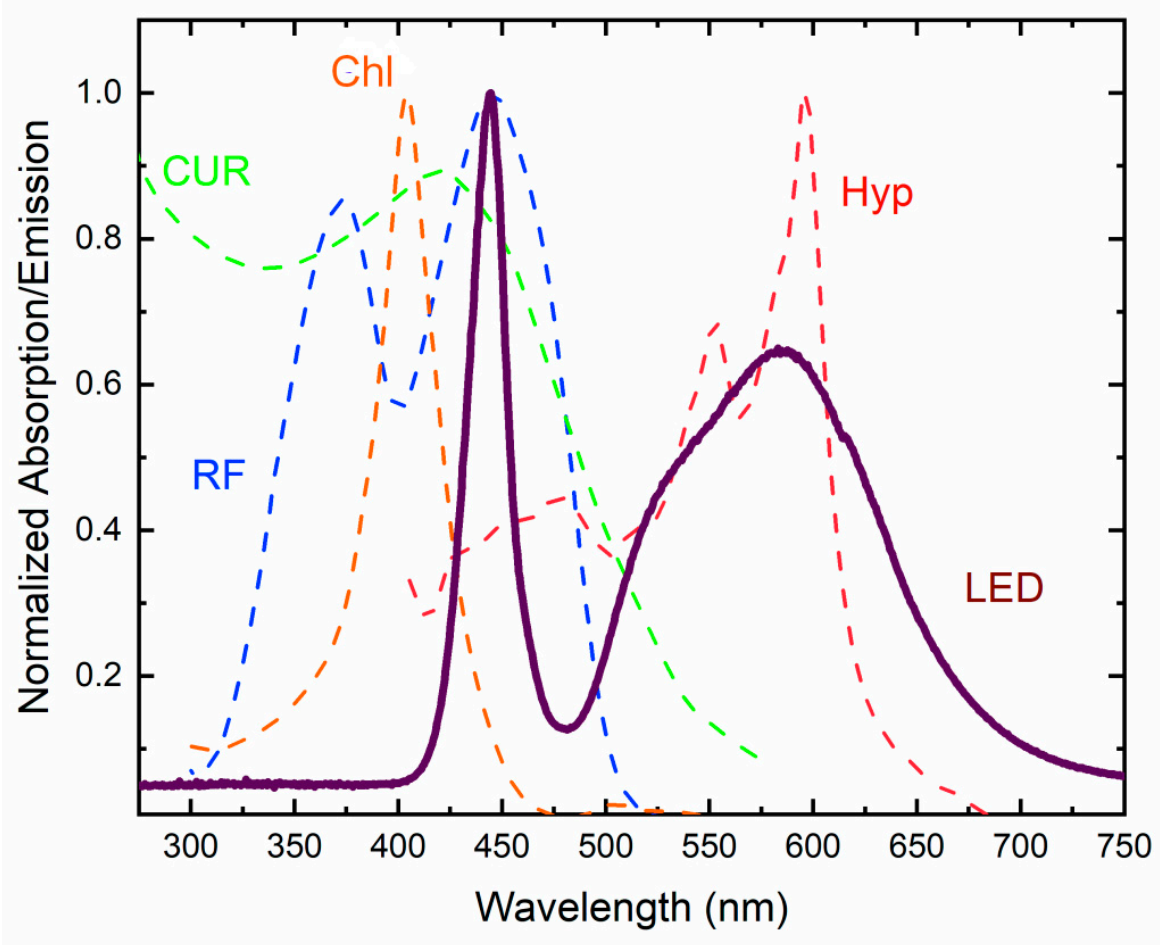

Figure 6. Absorption spectra of CUR [160], RF, sodium Chl, Hyp [113], and typical emission spectra of an LED (4000 K).

We can see that most of the PSs require high-photon-energy light of a blue color or even UV light. For the application of PSs for sterilization purposes on Earth or in spacecraft, the excitation by general illumination systems would be desirable. Any dedicated illumination/treatment system results in extra cost and weight, which is crucial for spacecraft. PSs such as CUR and RF show a good overlap with the "blue" part of white LED light, whereas Hyp can be excited by the phosphor-converted yellow-green light. On the other hand, PSs such as $\mathrm{Chl}$ and others requiring light of $<420 \mathrm{~nm}$ remain beyond 
the spectrum of modern (LED-based) general illumination spectra, requiring the implementation of dedicated illumination/treatment sources emitting light in the violet-UV spectral range.

Furthermore, the required illumination doses have to be discussed and compared with general illumination conditions. RF can be excited by blue light and requires from 3 to $400 \mathrm{~J} / \mathrm{cm}^{2}$ according to the data available in the literature (see Table S1 of Supplementary Material) [93-96,100-115,117-120, 138-146,148-150,153-161,165,173,175-182,186-201]. Typical illumination of a work plane according to the international norms is from 300 to $500 \mathrm{~lx}$ and does not exceed $1000 \mathrm{~lx}$ (except surgery). If typical LEDs of $4000 \mathrm{~K}$ are used (see Figure 6), (320 lm/W, the luminous efficacy of radiation), the surface irradiation ranges from 0.9 to $1.56 \mathrm{~W} / \mathrm{m}^{2}$ of white light spectrum $(400-700 \mathrm{~nm})$. Therefore, we have only 20 to $35 \mathrm{~mW} / \mathrm{cm}^{2}$ of blue light irradiance ( $22 \%$ of white). Illumination for $24 \mathrm{~h}$ provides an illumination dose of 1.73 to $3.01 \mathrm{~J} / \mathrm{cm}^{2}$. For Hyp, accepting a wider range of excitation, about two times' better overlap is observed, resulting in 3.5 to $6 \mathrm{~J} / \mathrm{cm}^{2}$ per day. Such doses can be a starting pointing for photoinactivation but are not always sufficient. Therefore, we have to conclude that the implementation of photoinactivation techniques for disinfection with the employment of general artificial lighting requires further study and scientific discussion since it is not clear if the photoinactivation dynamics measured for relatively short treatment times (up to a few hours) could be validated for a few days or weeks.

\section{Conclusions}

Biofilms play an important role in human infections and pose a potential threat to material integrity, not only in confined facilities such as hospital and food settings on Earth but also, in spacecraft. The dominant organisms are mostly associated with the microbiome of crewmembers' skin and largely contribute to both planktonic and biofilm microbial diversity of the spacecraft. Some of the bacteria may include opportunistic pathogens as well. According to the latest research on bacterial biofilm development in space conditions, biofilms are currently considered to pose a more significant threat as destroyers of abiotic surfaces of various forms of spacecraft equipment, rather than posing a health threat to the crewmembers. Nevertheless, some studies revealed that in spaceflight conditions, biofilms form faster and, therefore, can acquire antibiotic resistance faster, forming thicker structures and assuming different forms in space. Therefore, studies of longer duration are needed in order to correctly evaluate the possible effect of bacteria in space conditions on crewmembers' health and to investigate how their space-altered immune systems are able to respond to infections.

This review has also focused on the recent scientific literature concerning the efficiency of antimicrobial photoinactivation based on natural PSs (perylenequinones, riboflavin, curcumin, psoralens, and chlorophyllin) toward various bacterial species in planktonic and biofilm growth modes. It was found that a significant number of natural products and their derivatives have shown proven photodynamic antibacterial actions in confined on-ground settings, such as hospitals, and are also used in food protection. Therefore, API potentially could be applied in a closed spacecraft environment as a safe and non-toxic method, to which bacteria do not develop resistance. Nevertheless, the experimental data on biofilm control in the spacecraft environment, especially concerning natural antibacterial techniques, is currently episodic and requires more attention and scientific interest. Furthermore, the incorporation of practical illumination systems into spacecraft lighting is still somewhat obscure, and also requires further study.

Supplementary Materials: Supplementary Materials can be found at http://www.mdpi.com/1422-0067/21/18/ 6932/s1.

Author Contributions: Conceptualization, I.B., A.G., L.K. and P.V.; writing-original draft preparation, I.B. and A.G.; writing-review and editing, I.B., A.G. and P.V.; visualization, I.B., A.G. and P.V. The authors declare that I.B. and A.G. have contributed equally to the work. All authors have read and agreed to the published version of the manuscript.

Funding: Research was funded by the European Space Agency (LT5_1 ESA Contract No. 40000129495/19/NL/SSC).

Acknowledgments: The authors would like to thank Deimante Puryte for the help with the preparation of figures. 
Conflicts of Interest: The authors declare no conflict of interest.

\section{Abbreviations}

\begin{tabular}{ll} 
ISS & International Space Station \\
API & Antimicrobial photoinactivation \\
PS & Photosensitizer \\
ROS & Reactive oxygen species \\
CUR & Curcumin \\
RF & Riboflavin \\
Hyp & Hypericin \\
Chl & Chlorophyllin \\
EPS & Extracellular polymeric substances \\
LSMMG & Low-shear modeled microgravity \\
MRSA & Methicillin-resistant S. aureus \\
PWD & Portable water dispenser \\
TSB & Tryptic soy broth \\
PDT & Photodynamic therapy \\
DMSO & Dimethyl sulfoxyde \\
GS & Ground state \\
ES & Excited state \\
MSSA & Methicillin-susceptible S. aureus \\
PIA & Polysaccharide intercellular adhesin \\
HA & Hypocrellin A \\
HB & Hypocrellin B \\
FAD & Flavine adenine dinucleotide \\
FMN & Flavine mononucleotide \\
GRAS & Generally regarded as safe \\
FDA & Food and Drug Administration \\
FMF & Formylmethylflavine \\
LC & Lemichrome \\
LF & Lemiflavin \\
CMF & Carboxymethylflavin \\
PBS & Phosphate buffered saline \\
& \\
\hline
\end{tabular}

\section{References}

1. Mora, M.; Wink, L.; Kögler, I.; Mahnert, A.; Rettberg, P.; Schwendner, P.; DeMets, R.; Cockell, C.S.; Alekhova, T.; Klingl, A.; et al. Space Station conditions are selective but do not alter microbial characteristics relevant to human health. Nat. Commun. 2019, 10, 3990. [CrossRef]

2. Venkateswaran, K.; Vaishampayan, P.; Cisneros, J.; Pierson, D.L.; Rogers, S.O.; Perry, J. International Space Station environmental microbiome-Microbial inventories of ISS filter debris. Appl. Microbiol. Biotechnol. 2014, 98, 6453-6466. [CrossRef] [PubMed]

3. Zea, L.; Nisar, Z.; Rubin, P.; Cortesão, M.; Luo, J.; McBride, S.A.; Moeller, R.; Klaus, D.; Müller, D.; Varanasi, K.K.; et al. Design of a spaceflight biofilm experiment. Acta Astronaut. 2018, 148, $294-300$. [CrossRef] [PubMed]

4. Sobisch, L.Y.; Rogowski, K.M.; Fuchs, J.; Schmieder, W.; Vaishampayan, A.; Oles, P.; Novikova, N.; Grohmann, E. Biofilm forming antibiotic resistant gram-positive pathogens isolated from surfaces on the international space station. Front. Microbiol. 2019, 10, 543. [CrossRef] [PubMed]

5. Kim, W.; Tengra, F.K.; Shong, J.; Marchand, N.; Chan, H.K.; Young, Z.; Pangule, R.C.; Parra, M.; Dordick, J.S.; Plawsky, J.; et al. Effect of spaceflight on Pseudomonas aeruginosa final cell density is modulated by nutrient and oxygen availability. BMC Microbiol. 2013, 13, 241. [CrossRef]

6. Kim, W.; Tengra, F.K.; Young, Z.; Shong, J.; Marchand, N.; Chan, H.K.; Pangule, R.C.; Parra, M.; Dordick, J.S.; Plawsky, J.L.; et al. Spaceflight Promotes Biofilm Formation by Pseudomonas aeruginosa. PLoS ONE 2013, 8, e62437. [CrossRef] 
7. Zhang, Y.; Zhang, L.T.; Li, Z.D.; Xin, C.X.; Li, X.Q.; Wang, X.; Deng, Y. Microbiomes of China's space station during assembly, integration, and test operations. Microb. Ecol. 2019, 78, 631-650. [CrossRef]

8. Novikova, N.D.; De Boever, P.; Poddubko, S.; Deshevaya, E.; Polikarpov, N.; Rakova, N.; Coninx, I.; Mergeay, M. Survey of environmental biocontamination on board the International Space Station. Res. Microbiol. 2006, 157, 5-12. [CrossRef]

9. Wong, W.C.; Dudinsky, L.A.; Garcia, V.M.; Ott, C.M.; Castro, V.A. Efficacy of various chemical disinfectants on biofilms formed in spacecraft potable water system components. Biofouling 2010, 26, 583-586. [CrossRef]

10. Thompson, A.F.; English, E.L.; Nock, A.M.; Willsey, G.G.; Eckstrom, K.; Cairns, B.; Bavelock, M.; Tighe, S.; Foote, A.; Shulman, H.; et al. Characterizing species interactions that contribute to biofilm formation in a multispecies model of a potable water bacterial community. Microbiology 2019, 166, 34-43. [CrossRef]

11. Taylor, P.W. Impact of space flight on bacterial virulence and antibiotic susceptibility. Infect. Drug Resist. 2015, 8, 249-262. [CrossRef] [PubMed]

12. Probst, A.J.; Vaishampayan, P. Are we there yet? Understanding interplanetary microbial hitchhikers using molecular methods. Curr. Issues Mol. Biol. 2020, 38, 33-52. [CrossRef] [PubMed]

13. Klintworth, R.; Reher, H.; Viktorov, A.; Bohle, D. Biological induced corrosion of materials II: New test methods and experiences from MIR station. Acta Astronaut. 1999, 44, 569-578. [CrossRef]

14. Schiwon, K.; Arends, K.; Rogowski, K.M.; Fürch, S.; Prescha, K.; Sakinc, T.; Van Houdt, R.; Werner, G.; Grohmann, E. Comparison of antibiotic resistance, biofilm formation and conjugative transfer of staphylococcus and enterococcus isolates from international space station and antarctic research station Concordia. Microb. Ecol. 2013, 65, 638-651. [CrossRef] [PubMed]

15. Wainwright, M. Photodynamic antimicrobial chemotherapy (PACT). J. Antimicrob. Chemother. 1998, 42, 13-28. [CrossRef] [PubMed]

16. Nakonechny, F.; Nisnevitch, M. Aspects of photodynamic inactivation of bacteria. In Microorganisms; Blumenberg, M., Shaaban, M., Elgaml, A., Eds.; IntechOpen: London, UK, 2019; Chapter 7; pp. 1-21.

17. Brovko, L.; Meyer, A.; Tiwana, A.S.; Chen, W.; Liu, H.; Filipe, C.D.; Griffiths, M.W. Photodynamic treatment: A novel method for sanitation of food handling and food processing surfaces. J. Food Prot. 2009, 5, 926-1138. [CrossRef]

18. Abrahamse, H.; Hamblin, M.R. New photosensitizers for photodynamic therapy. Biochem. J. 2016, 473, 347-364. [CrossRef]

19. Ghorbani, J.; Rahban, D.; Aghamiri, S.; Teymouri, A.; Bahador, A. Photosensitizers in antibacterial photodynamic therapy: An overview. Laser Ther. 2018, 27, 293-302. [CrossRef]

20. Hamblin, M.R. Antimicrobial photodynamic inactivation: A bright new technique to kill resistant microbes. Curr. Opin. Microbiol. 2016, 33, 67-73. [CrossRef]

21. Woźniak, A.; Grinholc, M. Combined antimicrobial activity of photodynamic inactivation and antimicrobialsState of the art. Front. Microbiol. 2018, 9, 930. [CrossRef]

22. Donlan, R.M. Biofilms: Microbial life on surfaces. Emerg. Infect. Dis. 2002, 8, 881-890. [CrossRef] [PubMed]

23. Bar-On, Y.M.; Milo, R. Towards a quantitative view of the global ubiquity of biofilms. Nat. Rev. Genet. 2019, 17, 199-200. [CrossRef] [PubMed]

24. Jefferson, K.K. What drives bacteria to produce biofilms? FEMS Microbiol. Lett. 2004, 236, 163-173. [CrossRef] [PubMed]

25. Berlanga, M.; Guerrero, R. Living together in biofilms: The microbial cell factory and its biotechnological implications. Microb. Cell Factories 2016, 15, 165. [CrossRef]

26. Koo, H.; Allan, R.N.; Howlin, R.P.; Stoodley, P.; Hall-Stoodley, L. Targeting microbial biofilms: Current and prospective therapeutic strategies. Nat. Rev. Genet. 2017, 15, 740-755. [CrossRef]

27. La Duc, M.T.; Kern, R.; Venkateswaran, K. Microbial monitoring of spacecraft and associated environments. Microb. Ecol. 2004, 47, 150-158. [CrossRef]

28. Checinska, A.; Probst, A.J.; Vaishampayan, P.; White, J.R.; Kumar, D.; Stepanov, V.G.; Fox, G.E.; Nilsson, R.H.; Pierson, D.L.; Perry, J.; et al. Microbiomes of the dust particles collected from the international space station and spacecraft assembly facilities. Microbiome 2015, 3, 50. [CrossRef]

29. Koskinen, K.; Rettberg, P.; Pukall, R.; Auerbach, A.; Wink, L.; Barczyk, S.; Perras, A.; Mahnert, A.; Margheritis, D.; Kminek, G.; et al. Microbial biodiversity assessment of the European Space Agency's ExoMars 2016 mission. Microbiome 2017, 5, 143. [CrossRef] 
30. Perrin, E.; Bacci, G.; Garrelly, L.; Canganella, F.; Bianconi, G.; Fani, R.; Mengoni, A. The Biowyse Consortium Furnishing spaceship environment: Evaluation of bacterial biofilms on different materials used inside International Space Station. Res. Microbiol. 2018, 169, 289-295. [CrossRef]

31. Ichijo, T.; Yamaguchi, N.; Tanigaki, F.; Shirakawa, M.; Nasu, M. Four-year bacterial monitoring in the International Space Station-Japanese Experiment Module "Kibo" with culture-independent approach. NPJ Microgravity 2016, 2, 16007. [CrossRef]

32. Ichijo, T.; Hieda, H.; Ishihara, R.; Yamaguchi, N.; Nasu, M. Bacterial Monitoring with Adhesive Sheet in the International Space Station "Kibo", the Japanese Experiment Module. Microbes Environ. 2013, 28, $264-268$. [CrossRef] [PubMed]

33. Be, N.A.; Avila-Herrera, A.; Allen, J.E.; Singh, N.; Sielaff, A.C.; Jaing, C.; Venkateswaran, K. Whole metagenome profiles of particulates collected from the International Space Station. Microbiome 2017, 5, 81. [CrossRef] [PubMed]

34. Sielaff, A.C.; Urbaniak, C.; Mohan, G.B.M.; Stepanov, V.G.; Tran, Q.; Wood, J.M.; Minich, J.; McDonald, D.; Mayer, T.; Knight, R.; et al. Characterization of the total and viable bacterial and fungal communities associated with the International Space Station surfaces. Microbiome 2019, 7, 50. [CrossRef] [PubMed]

35. Mora, M.; Perras, A.; Alekhova, T.A.; Wink, L.; Krause, R.; Aleksandrova, A.; Novozhilova, T.; Moissl-Eichinger, C. Resilient microorganisms in dust samples of the International Space Station-Survival of the adaptation specialists. Microbiome 2016, 4, 65. [CrossRef]

36. Cogoli, A. The effect of space flight on human cellular immunity. Environ. Med. 1993, 37, 107-116.

37. Crucian, B.E.; Chouker, A.; Simpson, R.J.; Mehta, S.; Marshall, G.; Smith, S.M.; Zwart, S.R.; Heer, M.; Ponomarev, S.; Whitmire, A.; et al. Immune system dysregulation during spaceflight: Potential countermeasures for deep space exploration missions. Front. Immunol. 2018, 9, 1437. [CrossRef]

38. Decelle, J.G.; Taylor, G.R. Autoflora in the upper respiratory tract of Apollo astronauts. Appl. Environ. Microbiol. 1976, 32, 659-665. [CrossRef]

39. Castro, S.L.; Nelman-Gonzalez, M.; Nickerson, C.A.; Ott, C.M. Induction of attachment-independent biofilm formation and repression ofhfqexpression by low-fluid-shear culture of Staphylococcus aureus. Appl. Environ. Microbiol. 2011, 77, 6368-6378. [CrossRef] [PubMed]

40. Hammond, T.G.; Stodieck, L.; Birdsall, H.H.; Becker, J.L.; Koenig, P.; Hammond, J.S.; Gunter, M.A.; Allen, P.L. Effects of microgravity on the virulence of Listeria monocytogenes, Enterococcus faecalis, Candida albicans, and methicillin-resistant Staphylococcus aureus. Astrobiology 2013, 13, 1081-1090. [CrossRef]

41. O’Rourke, A.; Lee, M.D.; Nierman, W.C.; Everroad, R.C.; Dupont, C.L. Genomic and phenotypic characterization of Burkholderia isolates from the potable water system of the International Space Station. PLoS ONE 2020, 15, e0227152. [CrossRef]

42. La Duc, M.T.; Sumner, R.; Pierson, D.; Venkat, P.; Venkateswaran, K. Evidence of pathogenic microbes in the international space station drinking water: Reason for concern? Habitation 2004, 10, 39-48. [CrossRef] [PubMed]

43. Bruce, R.J.; Ott, C.M.; Skuratov, V.M.; Pierson, D.L. Microbial surveillance of potable water sources of the international space station. SAE Trans. 2005, 114, 283-292. [CrossRef]

44. Mora, M.; Mahnert, A.; Koskinen, K.; Păuşan, M.R.; Oberauner-Wappis, L.; Krause, R.; Perras, A.K.; Gorkiewicz, G.; Berg, G.; Moissl-Eichinger, C. Microorganisms in confined habitats: Microbial monitoring and control of intensive care units, operating rooms, cleanrooms and the international space station. Front. Microbiol. 2016, 7, 1573. [CrossRef] [PubMed]

45. Guéguinou, N.; Huin-Schohn, C.; Bascove, M.; Bueb, J.L.; Tschirhart, E.; Legrand-Frossi, C.; Frippiat, J.P. Could spaceflight-associated immune system weakening preclude the expansion of human presence beyond Earth's orbit? J. Leukoc. Biol. 2009, 86, 1027-1038. [CrossRef]

46. Vaishampayan, A.; Grohmann, E. Multi-resistant biofilm-forming pathogens on the international space station. J. Biosci. 2019, 44, 125. [CrossRef] [PubMed]

47. Urbaniak, C.; Sielaff, A.C.; Frey, K.G.; Allen, J.E.; Singh, N.; Jaing, C.; Wheeler, K.; Venkateswaran, K. Detection of antimicrobial resistance genes associated with the International Space Station environmental surfaces. Sci. Rep. 2018, 8, 814. [CrossRef]

48. Pyle, B.H.; McFeters, G.A.; Broadaway, S.C.; Johnsrud, C.K.; Storga, R.T.; Borkowski, J. Bacterial Growth on Surfaces and in Suspensions. Biorack on Spacehab. Biological Experiments on Shuttle to Mir Missions 03, 05, and 06; European Space Agency: Noordwijk, The Netherlands, 1999; pp. 95-99. 
49. McLean, R.J.C.; Cassanto, J.M.; Barnes, M.B.; Koo, J.H. Bacterial biofilm formation under microgravity conditions. FEMS Microbiol. Lett. 2001, 195, 115-119. [CrossRef]

50. Lynch, S.V.; Mukundakrishnan, K.; Benoit, M.R.; Ayyaswamy, P.S.; Matin, A.C. Escherichia coli biofilms formed under low-shear modeled microgravity in a ground-based system. Appl. Environ. Microbiol. 2006, 72, 7701-7710. [CrossRef]

51. Wilson, J.W.; Ott, C.M.; Zu Bentrup, K.H.; Ramamurthy, R.; Quick, L.; Porwollik, S.; Cheng, P.; McClelland, M.; Tsaprailis, G.; Radabaugh, T.; et al. Space flight alters bacterial gene expression and virulence and reveals a role for global regulator Hfq. Proc. Natl. Acad. Sci. USA 2007, 104, 16299-16304. [CrossRef]

52. Aunins, T.R.; Erickson, K.E.; Prasad, N.; Levy, S.E.; Jones, A.; Shrestha, S.; Mastracchio, R.; Stodieck, L.; Klaus, D.; Zea, L.; et al. Spaceflight modifies Escherichia coli gene expression in response to antibiotic exposure and reveals role of oxidative stress response. Front. Microbiol. 2018, 9, 310. [CrossRef]

53. Fernandez-Barat, L.; Motos, A.; Panigada, M.; Álvarez-Lerma, F.; Viña, L.; Lopez-Aladid, R.; Ceccato, A.; Bassi, G.L.; Nicolau, D.P.; Lopez, Y.; et al. Comparative efficacy of linezolid and vancomycin for endotracheal tube MRSA biofilms from ICU patients. Crit. Care 2019, 23, 251. [CrossRef] [PubMed]

54. Akturk, E.; Oliveira, H.; Santos, S.B.; Costa, S.; Kuyumcu, S.; Melo, L.D.R.; Azeredo, J. Synergistic action of phage and antibiotics: Parameters to enhance the killing efficacy against mono and dual-species biofilms. Antibiotics 2019, 8, 103. [CrossRef] [PubMed]

55. Melian, C.; Segli, F.; Gonzalez, R.; Vignolo, G.; Castellano, P. Lactocin AL705 as quorum sensing inhibitor to control Listeria monocytogenes biofilm formation. J. Appl. Microbiol. 2019, 127, 911-920. [CrossRef] [PubMed]

56. Pham, D.T.N.; Khan, F.; Phan, T.T.V.; Park, S.K.; Manivasagan, P.; Oh, J.; Kim, Y.-M. Biofilm inhibition, modulation of virulence and motility properties by $\mathrm{FeOOH}$ nanoparticle in Pseudomonas aeruginosa. Braz. J. Microbiol. 2019, 50, 791-805. [CrossRef]

57. Fallatah, H.; Elhaneid, M.; Ali-Boucetta, H.; Overton, T.; El Kadri, H.; Gkatzionis, K. Antibacterial effect of graphene oxide (GO) nano-particles against Pseudomonas putida biofilm of variable age. Environ. Sci. Pollut. Res. 2019, 26, 25057-25070. [CrossRef]

58. Qiu, H.; Pu, F.; Liu, Z.; Deng, Q.; Sun, P.; Ren, J.; Qu, X. Depriving bacterial adhesion-related molecule to inhibit biofilm formation using $\mathrm{CeO}_{2}$-decorated metal-organic frameworks. Small 2019, 15, e1902522. [CrossRef]

59. Ferrer-Espada, R.; Liu, X.; Goh, X.S.; Dai, T. Antimicrobial blue light inactivation of polymicrobial biofilms. Front. Microbiol. 2019, 10, 721. [CrossRef]

60. Prado, D.B.D.; Szczerepa, M.M.D.A.; Capeloto, O.A.; Astrath, N.G.C.; Dos Santos, N.C.A.; Previdelli, I.T.S.; Nakamura, C.V.; Mikcha, J.M.G.; Filho, B.A.D.A.; Dos Santos, N.C.A. Effect of ultraviolet (UV-C) radiation on spores and biofilms of Alicyclobacillus spp. in industrialized orange juice. Int. J. Food Microbiol. 2019, 305, 108238. [CrossRef]

61. Li, C.H.; Chen, X.; Landis, R.F.; Geng, Y.; Makabenta, J.M.; Lemnios, W.; Gupta, A.; Rotello, V. Phytochemicalbased nanocomposites for the treatment of bacterial biofilms. ACS Infect. Dis. 2019, 5, 1590-1596. [CrossRef]

62. De Oliveira, A.B.; Ferrisse, T.M.; Marques, R.S.; De Annunzio, S.R.; Brighenti, F.L.; Fontana, C.R. Effect of photodynamic therapy on microorganisms responsible for dental caries: A systematic review and meta-analysis. Int. J. Mol. Sci. 2019, 20, 3585. [CrossRef]

63. Vögeling, H.; Plenagl, N.; Seitz, B.S.; Duse, L.; Pinnapireddy, S.R.; Dayyoub, E.; Jedelska, J.; Brüßler, J.; Bakowsky, U.; Pinapireddy, S.R. Synergistic effects of ultrasound and photodynamic therapy leading to biofilm eradication on polyurethane catheter surfaces modified with hypericin nanoformulations. Mater. Sci. Eng. C Mater. Biol. Appl. 2019, 103, 109749. [CrossRef] [PubMed]

64. Picco, D.D.C.R.; Cavalcante, L.L.R.; Trevisan, R.L.B.; Souza-Gabriel, A.E.; Borsatto, M.C.; Corona, S.A.M. Effect of curcumin-mediated photodynamic therapy on Streptococcus mutans and Candida albicans: A systematic review of in vitro studies. Photodiagnosis Photodyn. Ther. 2019, 27, 455-461. [CrossRef]

65. Lim, E.S.; Koo, O.K.; Kim, M.J.; Kim, J.S. Bio-enzymes for inhibition and elimination of Escherichia coli O157:H7 biofilm and their synergistic effect with sodium hypochlorite. Sci. Rep. 2019, 9, 9920. [CrossRef] [PubMed]

66. Landau, U.; Lisowsky, T.; Karlheinz, E.; Mehler, K. Bioactive, Ruthenium-Containing Coating and Device. U.S. Patent No. EP 2077976 B1, 18 May 2016.

67. Berg, G.; Liebminger, S.; Oberauner, L.; Klein, T.; Stampf, R. Photodynamic Control of Microbal Growth on Surfaces. U.S. Patent No. 201401 19985A1, 1 May 2014. 
68. Luksienè, Z.; Buchovec, I. Method of Decontamination of Food and Food Related Surfaces. Lithuania Patent No. LT 5567 B, 25 February 2009.

69. Denis, T.G.S.; Hamblin, M.R. An introduction to photoantimicrobials: Photodynamic therapy as a novel method of microbial pathogen eradication. In Science against Microbial Pathogens: Communicating Current Research and Technological Advances, 3rd ed.; Mendez-Vilas, A., Ed.; Formatex Research Center: Badajoz, Spain, 2011; pp. 675-683.

70. Luksiene, Z.; Brovko, L. Antibacterial photosensitization-based treatment for food safety. Food Eng. Rev. 2013, 5, 185-199. [CrossRef]

71. Alves, E.; Faustino, M.A.F.; Neves, M.G.P.M.S.; Cunha, A.; Tome, J.P.C.; Almeida, A. An insight on bacterial cellular targets of photodynamic inactivation. Future Med. Chem. 2014, 6, 141-164. [CrossRef]

72. Wainwright, M.; Maisch, T.; Nonell, S.; Plaetzer, K.; Almeida, A.; Tegos, G.P.; Hamblin, M.R. Photoantimicrobials-Are we afraid of the light? Lancet Infect. Dis. 2017, 17, 49-55. [CrossRef]

73. Huang, L.; Xuan, Y.; Koide, Y.; Zhiyentayev, T.; Tanaka, M.; Hamblin, M.R. Type I and Type II mechanisms of antimicrobial photodynamic therapy: An in vitro study on gram-negative and gram-positive bacteria. Lasers Surg. Med. 2012, 44, 490-499. [CrossRef]

74. Liu, Y.; Qin, R.; Zaat, S.A.J.; Breukink, E.; Heger, M. Antibacterial photodynamic therapy: Overview of a promising approach to fight antibiotic-resistant bacterial infections. J. Clin. Transl. Res. 2015, 1, 140-167.

75. Cieplik, F.; Deng, D.; Crielaard, W.; Buchalla, W.; Hellwig, E.; Al-Ahmad, A.; Maisch, T. Antimicrobial photodynamic therapy-What we know and what we don't. Crit. Rev. Microbiol. 2018, 44, 571-589. [CrossRef]

76. Huang, L.; Denis, T.G.S.; Xuan, Y.; Huang, Y.-Y.; Tanaka, M.; Zadlo, A.; Sarna, T.; Hamblin, M.R. Paradoxical potentiation of methylene blue-mediated antimicrobial photodynamic inactivation by sodium azide: Role of ambient oxygen and azide radicals. Free Radic. Biol. Med. 2012, 53, 2062-2071. [CrossRef]

77. Fotinos, N.; Convert, M.; Piffaretti, J.C.; Gurny, R.; Lange, N. Effects on gram-negative and gram-positive bacteria mediated by 5-aminolevulinic acid and 5-aminolevulinic acid derivatives. Antimicrob. Agents Chemother. 2008, 52, 1366-1373. [CrossRef] [PubMed]

78. Jori, G.; Fabris, C.; Soncin, M.; Ferro, S.; Coppellotti, O.; Dei, D.; Fantetti, L.; Chiti, G.; Roncucci, G. Photodynamic therapy in the treatment of microbial infections: Basic principles and perspective applications. Lasers Surg. Med. 2006, 38, 468-481. [CrossRef] [PubMed]

79. Hamblin, M.R.; Abrahamse, H. Oxygen-independent antimicrobial photoinactivation: Type III photochemical mechanism? Antibiotics 2020, 9, 53. [CrossRef]

80. Brovko, L. Photodynamic treatment: A new efficient alternative for surface sanitation. In Advances in Food and Nutrition Research; Taylor, S., Ed.; Academic Press: Cambridge, MA, USA, 2010; pp. 120-147.

81. Maisch, T. Resistance in antimicrobial photodynamic inactivation of bacteria. Photochem. Photobiol. Sci. 2015, 14, 1518-1526. [CrossRef] [PubMed]

82. Hamblin, M.R.; Hasan, T. Photodynamic therapy: A new antimicrobial approach to infectious disease? Photochem. Photobiol. Sci. 2004, 3, 436-450. [CrossRef]

83. Malik, Z.; Ladan, H.; Nitzan, Y. Photodynamic inactivation of Gram-negative bacteria: Problems and possible solutions. J. Photochem. Photobiol. B Biol. 1992, 14, 262-266. [CrossRef]

84. Nitzan, Y.; Salmon-Divon, M.; Shporen, E.; Malik, Z. ALA induced photodynamic effects on Gram positive and negative bacteria. Photochem. Photobiol. Sci. 2004, 3, 430-435. [CrossRef]

85. Sperandio, F.F.; Huang, Y.-Y.; Hamblin, M.R. Antimicrobial photodynamic therapy to kill Gram-negative bacteria. Recent Pat. Antiinfect. Drug Discov. 2013, 8, 108-120. [CrossRef]

86. Callaghan, S.; Senge, M.O. The good, the bad, and the ugly-Controlling singlet oxygen through design of photosensitizers and delivery systems for photodynamic therapy. Photochem. Photobiol. Sci. 2018, 17, 1490-1514. [CrossRef]

87. Maisch, T. Strategies to optimize photosensitizers for photodynamic inactivation of bacteria. J. Photochem. Photobiol. B Biol. 2015, 150, 2-10. [CrossRef]

88. Yin, R.; Hamblin, M. Antimicrobial photosensitizers: Drug discovery under the spotlight. Curr. Med. Chem. 2015, 22, 2159-2185. [CrossRef] [PubMed]

89. Yin, R.; Wang, M.; Huang, Y.-Y.; Landi, G.; Vecchio, D.; Chiang, L.Y.; Hamblin, M.R. Antimicrobial photodynamic inactivation with decacationic functionalized fullerenes: Oxygen-independent photokilling in presence of azide and new mechanistic insights. Free Radic. Biol. Med. 2014, 79, 14-27. [CrossRef] [PubMed] 
90. Nitzan, Y.; Pechatnikov, I. Approaches to kill gram-negative bacteria by photosensitized process. In Photodynamic Inactivation of Microbial Pathogens: Medical and Environmental Applications; Hamblin, M.R., Ed.; RSC Publishing: Cambridge, UK, 2011; Volume 87, pp. 47-67.

91. Saw, C.L.L. Science against microbial pathogens: Photodynamic therapy approaches. In Science against Microbial Pathogens: Communicating Current Research and Technological Advances; Mendez-Vilas, A., Ed.; Formatex Publishing: Badajor, India, 2011; pp. 668-674.

92. Demidova, T.N.; Hamblin, M.R. Effect of cell-photosensitizer binding and cell density on microbial photoinactivation effect of cell-photosensitizer binding and cell density on microbial photoinactivation. Antimicrob. Agents Chemother. 2005, 49, 2329-2335. [CrossRef] [PubMed]

93. Luksiene, Z.; Buchovec, I.; Paskeviciute, E. Inactivation of Bacillus cereus by Na-chlorophyllin-based photosensitization on the surface of packaging. J. Appl. Microbiol. 2010, 109, 1540-1548. [CrossRef]

94. Krüger, M.; Richter, P.R.; Strauch, S.M.; Nasir, A.; Burkovski, A.; Antunes, C.A.; Meißgeier, T.; Schluecker, E.; Schwab, S.; Lebert, M. What an escherichia coli mutant can teach us about the antibacterial effect of chlorophyllin. Microorganisms 2019, 7, 59. [CrossRef]

95. Mamone, L.; Di Venosa, G.; Gándara, L.; Sáenz, D.; Vallecorsa, P.; Schickinger, S.; Rossetti, M.; Batlle, A.; Buzzola, F.R.; Casas, A. Photodynamic inactivation of Gram-positive bacteria employing natural resources. J. Photochem. Photobiol. B Biol. 2014, 133, 80-89. [CrossRef]

96. Majiya, H.; Galstyan, A. Dye extract of calyces of Hibiscus sabdariffa has photodynamic antibacterial activity: A prospect for sunlight-driven fresh produce sanitation. Food Sci. Nutr. 2020, 8, 3200-3211. [CrossRef]

97. Falk, H.; Meyer, J.; Oberreiter, M. A convenient semisynthetic route to hypericin. Monatshefte Chem. 1993, 124, 339-341. [CrossRef]

98. Kubin, A.; Loew, H.G.; Burner, U.; Jessner, G.; Kolbabek, H.; Wierrani, F. How to make hypericin water-soluble. Die Pharm. 2008, 63, 263-269.

99. Ehrenberg, B.; Anderson, J.; Foote, C. Kinetics and yield of singlet oxygen photosensitized by hypericin in organic and biological media. Photochem. Photobiol. 1998, 68, 135-140. [CrossRef]

100. Alam, S.T.; Le, T.A.N.; Park, J.S.; Kwon, H.C.; Kang, K. Antimicrobial biophotonic treatment of ampicillin-resistant Pseudomonas aeruginosa with hypericin and ampicillin cotreatment followed by orange light. Pharmaceutics 2019, 11, 641. [CrossRef] [PubMed]

101. Comas-Barceló, J.; Rodríguez-Amigo, B.; Abbruzzetti, S.; Del Rey-Puech, P.; Agut, M.; Nonell, S.; Viappiani, C. A self-assembled nanostructured material with photosensitising properties. RSC Adv. 2013, 3, 17874-17879. [CrossRef]

102. Delcanale, P.; Rodríguez-Amigo, B.; Jiménez, J.J.; Luque, F.J.; Abbruzzetti, S.; Agut, M.; Nonell, S.; Viappiani, C. Tuning the local solvent composition at a drug carrier surface: The effect of dimethyl sulfoxide/water mixture on the photofunctional properties of hypericin- $\beta$-lactoglobulin complexes. J. Mater. Chem. B 2017, 5, 1633-1641. [CrossRef] [PubMed]

103. Delcanale, P.; Hally, C.; Nonell, S.; Bonardi, S.; Viappiani, C.; Abbruzzetti, S. Photodynamic action of Hypericum perforatum hydrophilic extract against Staphylococcus aureus. Photochem. Photobiol. Sci. 2020, 19, 324-331. [CrossRef]

104. Engelhardt, V.; Krammer, B.; Plaetzer, K. Antibacterial photodynamic therapy using water-soluble formulations of hypericin or mTHPC is effective in inactivation of Staphylococcus aureus. Photochem. Photobiol. Sci. 2010, 9, 365-369. [CrossRef]

105. García, I.; Ballesta, S.; Gilaberte, Y.; Rezusta, A.; Pascual, A. Antimicrobial photodynamic activity of hypericin against methicillin-susceptible and resistant Staphylococcus aureus biofilms. Future Microbiol. 2015, 10, 347-356. [CrossRef]

106. Kashef, N.; Borghei, Y.S.; Djavid, G.E. Photodynamic effect of hypericin on the microorganisms and primary human fibroblasts. Photodiagnosis Photodyn. Ther. 2013, 10, 150-155. [CrossRef]

107. Kashef, N.; Karami, S.; Djavid, G.E. Phototoxic effect of hypericin alone and in combination with acetylcysteine on Staphylococcus aureus biofilms. Photodiagn. Photodyn. Ther. 2015, 12, 186-192. [CrossRef]

108. Melo, W.C.M.A.; Lee, A.N.; Perussi, J.R.; Hamblin, M.R. Electroporation enhances antimicrobial photodynamic therapy mediated by the hydrophobic photosensitizer, hypericin. Photodiagn. Photodyn. Ther. 2013, 10, 647-650. [CrossRef] 
109. Rodríguez-Amigo, B.; Delcanale, P.; Rotger, G.; Jiménez, J.J.; Abbruzzetti, S.; Summer, A.; Agut, M.; Luque, F.J.; Nonell, S.; Viappiani, C. The complex of hypericin with $\beta$-lactoglobulin has antimicrobial activity with potential applications in dairy industry. J. Dairy Sci. 2015, 98, 89-94. [CrossRef]

110. Yow, C.M.N.; Tang, H.M.; Chu, E.S.; Huang, Z. Hypericin-mediated Photodynamic Antimicrobial Effect on Clinically Isolated Pathogenst. Photochem. Photobiol. 2012, 88, 626-632. [CrossRef] [PubMed]

111. Lüthi, M.; Gyenge, E.B.; Engstrüm, M.; Bredell, M.; Gratz, K.; Walt, H.; Gmür, R.; Maake, C. Hypericin- and mTHPC-mediated photodynamic therapy for the treatment of cariogenic bacteria. Med. Laser Appl. 2009, 24, 227-236. [CrossRef]

112. Kairyte, K.; Lapinskas, S.; Gudelis, V.; Luksiene, Z. Effective inactivation of food pathogens Listeria monocytogenes and Salmonella enterica by combined treatment of hypericin-based photosensitization and high power pulsed light. J. Appl. Microbiol. 2012, 112, 1144-1151. [CrossRef] [PubMed]

113. Aponiene, K.; Paskeviciute, E.; Reklaitis, I.; Luksiene, Z. Reduction of microbial contamination of fruits and vegetables by hypericin-based photosensitization: Comparison with other emerging antimicrobial treatments. J. Food Eng. 2015, 144, 29-35. [CrossRef]

114. Jankowski, A.; Jankowski, S.; Mirończyk, A.; Niedbach, J. The action of photosensitizers and serum in a bactericidal process. II. The effects of dyes: Hypericin, eosin Y and saphranine O. Pol. J. Microbiol. 2005, 54, 323-330. [PubMed]

115. Zhang, J.N.; Zhang, F.; Tang, Q.J.; Xu, C.S.; Meng, X.H. Effect of photodynamic inactivation of Escherichia coli by hypericin. World J. Microbiol. Biotechnol. 2018, 34, 100. [CrossRef] [PubMed]

116. Krishnaswami, V.; Ponnusamy, C.; Sankareswaran, S.; Paulsamy, M.; Madiyalakan, R.; Palanichamy, R.; Kandasamy, R.; Natesan, S.; Madiyalakan, M.; Palanisamy, R. Development of copolymeric nanoparticles of hypocrellin B: Enhanced phototoxic effect and ocular distribution. Eur. J. Pharm. Sci. 2018, 116, 26-36. [CrossRef]

117. Jiang, Y.; Leung, A.W.; Wang, X.; Zhang, H.; Xu, C. Inactivation of Staphylococcus aureus by photodynamic action of hypocrellin B. Photodiagn. Photodyn. Ther. 2013, 10, 600-606. [CrossRef]

118. Jiang, Y.; Leung, W.-N.; Tang, Q.; Zhang, H.; Xu, C. Effect of light-activated hypocrellin b on the growth and membrane permeability of gram-negative Escherichia coli cells. Int. J. Photoenergy 2014, 2014, 521209. [CrossRef]

119. Otieno, W.; Liu, C.; Deng, H.; Li, J.; Zeng, X.; Ji, Y. Hypocrellin B-mediated photodynamic inactivation of gram-positive antibiotic-resistant bacteria: An in vitro study. Photobiomodul. Photomed. Laser Surg. 2020, 38, 36-42. [CrossRef]

120. Su, Y.; Sun, J.; Rao, S.; Cai, Y.; Yang, Y. Photodynamic antimicrobial activity of hypocrellin A. J. Photochem. Photobiol. B Biol. 2011, 103, 29-34. [CrossRef] [PubMed]

121. Rezusta, A.; Rezusta-López, A.; Paz-Cristobal, M.P.; Alemany-Ribes, M.; Royo-Díez, D.; Agut, M.; Semino, C.; Nonell, S.; Revillo, M.J.; Aspiroz, C.; et al. In vitro fungicidal photodynamic effect of hypericin on Candida species. Photochem. Photobiol. 2011, 88, 613-619. [CrossRef] [PubMed]

122. Paz-Cristobal, M.P.; Gilaberte, Y.; Alejandre, C.; Pardo, J.; Revillo, M.J.; Rezusta, A. In vitro fungicidal photodynamic effect of hypericin on Trichophyton spp. Mycopathologia 2014, 178, 221-225. [CrossRef] [PubMed]

123. Hudson, J.; Harris, L.; Towers, G. The importance of light in the anti-HIV effect of hypericin. Antivir. Res. 1993, 20, 173-178. [CrossRef]

124. Prince, A.M.; Pascual, D.; Meruelo, D.; Liebes, L.; Mazur, Y.; Dubovi, E.; Mandel, M.; Lavie, G. Strategies for evaluation of enveloped virus inactivation in red cell concentrates using hypericin. Photochem. Photobiol. 2000, 71, 188-195. [CrossRef]

125. Gulick, R.M.; McAuliffe, V.; Holden-Wiltse, J.; Crumpacker, C.; Liebes, L.; Stein, D.S.; Meehan, P.; Hussey, S.; Forcht, J.; Valentine, F.T. Phase I studies of hypericin, the active compound in St. John's Wort, as an antiretroviral agent in HIV-infected adults. AIDS Clinical Trials Group Protocols 150 and 258. Ann. Intern. Med. 1999, 130, 510-514. [CrossRef] [PubMed]

126. Jacobson, J.M.; Feinman, L.; Liebes, L.; Ostrow, N.; Koslowski, V.; Tobia, A.; Cabana, B.E.; Lee, D.H.; Spritzler, J.; Prince, A.M. Pharmacokinetics, safety, and antiviral effects of hypericin, a derivative of St. John's wort plant, in patients with chronic hepatitis c virus infection. Antimicrob. Agents Chemother. 2001, 45, 517-524. [CrossRef] 
127. Jendželovská, Z.; Jendželovský, R.; Kuchárová, B.; Fedoročko, P. Hypericin in the light and in the dark: Two sides of the same coin. Front. Plant Sci. 2016, 7, 560. [CrossRef]

128. Cardoso, D.R.; Libardi, S.H.; Skibsted, L.H. Riboflavin as a photosensitizer. Effects on human health and food quality. Food Funct. 2012, 3, 487-502. [CrossRef]

129. Huang, R.; Choe, E.; Min, D. Kinetics for singlet oxygen formation by riboflavin photosensitization and the reaction between riboflavin and singlet oxygen. J. Food Sci. 2006, 69, C726-C732. [CrossRef]

130. Ahmad, I.; Anwar, Z.; Ahmed, S.; Sheraz, M.A.; Bano, R.; Hafeez, A. Solvent effect on the photolysis of riboflavin. AAPS PharmSciTech 2015, 16, 1122-1128. [CrossRef] [PubMed]

131. Sheraz, M.A.; Kazi, S.H.; Ahmed, S.; Anwar, Z.; Ahmad, I. Photo, thermal and chemical degradation of riboflavin. Beilstein J. Org. Chem. 2014, 10, 1999-2012. [CrossRef]

132. Ahgilan, A.; Sabaratnam, V.; Periasamy, V. Antimicrobial properties of vitamin B2. Int. J. Food Prop. 2016, 19, 1173-1181. [CrossRef]

133. Choe, E.; Huang, R.; Min, D.B. Chemical reactions and stability of riboflavin in foods. J. Food Sci. 2004, 70, 726-732. [CrossRef]

134. Silva, E.; Edwards, A.M.; Pacheco, D. Visible light-induced photooxidation of glucose sensitized by riboflavin. J. Nutr. Biochem. 1999, 10, 181-185. [CrossRef]

135. Ionita, P.; Matei, I. Application of Riboflavin Photochemical Properties in Hydrogel Synthesis. In Biophysical Chemistry-Advance Application; Khalid, M.A.A., Ed.; IntechOpen: London, UK, 2019; Chapter 2; pp. 1-15.

136. Chan, T.C.Y.; Lau, T.W.S.; Lee, J.W.Y.; Wong, I.Y.H.; Jhanji, V.; Wong, R.L. Corneal collagen cross-linking for infectious keratitis: An update of clinical studies. Acta Ophthalmol. 2015, 93, 689-696. [CrossRef]

137. Ettinger, A.; Miklauz, M.M.; Bihm, D.J.; Maldonado-Codina, G.; Goodrich, R.P. Preparation of cryoprecipitate from riboflavin and UV light-treated plasma. Transfus. Apher. Sci. 2012, 46, 153-158. [CrossRef]

138. Halili, F.; Arboleda, A.; Durkee, H.; Taneja, M.; Miller, D.; Alawa, K.A.; Aguilar, M.C.; Amescua, G.; Flynn, H.W.; Parel, J.M. Rose Bengal and riboflavin-mediated photodynamic therapy to inhibit methicillin-resistant Staphylococcus aureus keratitis isolates. Am. J. Ophthalmol. 2016, 166, 194-202. [CrossRef]

139. O'Rourke, J.F.; Dowds, B.C. Dye-mediated photodynamic inactivation of Bacillus subtilis. Biochem. Soc. Trans. 1992, 20, 76S. [CrossRef]

140. Kashiwabuchi, R.T.; Khan, Y.; Carvalho, F.R.D.S.; Hirai, F.; Campos, M.; McDonnell, P.J. Antimicrobial susceptibility of photodynamic therapy (UVA/riboflavin) against Staphylococcus aureus. Arq. Bras. Ophthalmol. 2012, 75, 423-426. [CrossRef]

141. Bäckman, A.; Makdoumi, K.; Mortensen, J.; Crafoord, S. The efficiency of cross-linking methods in eradication of bacteria is influenced by the riboflavin concentration and the irradiation time of ultraviolet light. Acta Ophthalmol. 2014, 92, 656-661. [CrossRef] [PubMed]

142. Makdoumi, K.; Bäckman, A.; Mortensen, J.; Crafoord, S. Evaluation of antibacterial efficacy of photo-activated riboflavin using ultraviolet light (UVA). Graefes Arch. Clin. Exp. Ophthalmol. 2009, 248, 207-212. [CrossRef] [PubMed]

143. Makdoumi, K.; Bäckman, A. Photodynamic UVA-riboflavin bacterial elimination in antibiotic resistant bacteria. Clin. Exp. Ophthalmol. 2016, 44, 582-586. [CrossRef] [PubMed]

144. Makdoumi, K.; Goodrich, R.P.; Bäckman, A. Photochemical eradication of methicillin-resistant Staphylococcus aureus by blue light activation of riboflavin. Acta Ophthalmol. 2017, 95, 498-502. [CrossRef]

145. Makdoumi, K.; Hedin, M.; Bäckman, A. Different photodynamic effects of blue light with and without riboflavin on methicillin-resistant Staphylococcus aureus (MRSA) and human keratinocytes in vitro. Lasers Med. Sci. 2019, 34, 1799-1805. [CrossRef]

146. Maisch, T.; Eichner, A.; Späth, A.; Gollmer, A.; Koenig, B.; Regensburger, J.; Bäumler, W. Fast and effective photodynamic inactivation of multiresistant bacteria by cationic riboflavin derivatives. PLoS ONE 2014, 9, e111792. [CrossRef]

147. Eitenmiller, R.; Ye, L.; Landen, W. Vitamin Analysis for the Health and Food Sciences, 2nd ed.; CRC Press: Boca Raton, FL, USA, 2008; p. 664.

148. Thakuri, P.S.; Joshi, R.; Basnet, S.; Pandey, S.; Taujale, S.D.; Mishra, N. Antibacterial photodynamic therapy on Staphylococcus aureus and Pseudomonas aeruginosa in-vitro. Nepal. Med. Coll. J. 2011, 13, 281-284.

149. Liang, J.Y.; Cheng, C.W.; Yu, C.H.; Chen, L.Y. Investigations of blue light-induced reactive oxygen species from flavin mononucleotide on inactivation of E. coli. J. Photochem. Photobiol. B Biol. 2015, 143, 82-88. [CrossRef] 
150. Wong, T.; Cheng, C.; Hsieh, Z.; Liang, J. Effects of blue or violet light on the inactivation of Staphylococcus aureus by riboflavin-5'-phosphate photolysis. J. Photochem. Photobiol. B Biol. 2013, 173, 672-680. [CrossRef]

151. Cozzolino, M.; Delcanale, P.; Montali, C.; Tognolini, M.; Giorgio, C.; Corrado, M.; Cavanna, L.; Bianchini, P.; Diaspro, A.; Abbruzzetti, S.; et al. Enhanced photosensitizing properties of protein bound curcumin. Life Sci. 2019, 223, 116710. [CrossRef]

152. Das, K.C.; Das, C.K. Curcumin (diferuloylmethane), a singlet oxygen $\left({ }^{1} \mathrm{O}_{2}\right)$ quencher. Biochem. Biophys. Res. Commun. 2002, 295, 62-66. [CrossRef]

153. De Annunzio, S.R.; De Freitas, L.M.; Blanco, A.L.; Da Costa, M.M.; Carmona-Vargas, C.C.; De Oliveira, K.T.; Fontana, C.R. Susceptibility of Enterococcus faecalis and Propionibacterium acnes to antimicrobial photodynamic therapy. J. Photochem. Photobiol. B Biol. 2018, 178, 545-550. [CrossRef]

154. Da Frota, M.F.; Guerreiro-Tanomaru, J.M.; Tanomaru-Filho, M.; Bagnato, V.S.; Espir, C.G.; Berbert, F.L.C.V. Photodynamic therapy in root canals contaminated with Enterococcus faecalis using curcumin as photosensitizer. Lasers Med. Sci. 2014, 30, 1867-1872. [CrossRef] [PubMed]

155. Haukvik, T.; Bruzell, E.; Kristensen, S.; Tønnesen, H.H. Photokilling of bacteria by curcumin in different aqueous preparations. Studies on curcumin and curcuminoids XXXVII. Pharmazie 2009, 64, 666-673. [PubMed]

156. Pileggi, G.; Wataha, J.C.; Girard, M.; Grad, I.; Schrenzel, J.; Lange, N.; Bouillaguet, S.D.M.D. Blue light-mediated inactivation of Enterococcus faecalis in vitro. Photodiagn. Photodyn. Ther. 2013, 10, 134-140. [CrossRef] [PubMed]

157. Manoil, D.; Filieri, A.; Gameiro, C.; Lange, N.; Schrenzel, J.; Wataha, J.C.; Bouillaguet, S. Flow cytometric assessment of Streptococcus mutans viability after exposure to blue light-activated curcumin. Photodiagn. Photodyn. Ther. 2014, 11, 372-379. [CrossRef]

158. Paschoal, M.A.B.; Lin, M.; Santos-Pinto, L.; Duarte, S. Photodynamic antimicrobial chemotherapy on Streptococcus mutans using curcumin and toluidine blue activated by a novel LED device. Lasers Med. Sci. 2015, 30, 885-890. [CrossRef]

159. Paschoal, M.A.B.; Tonon, C.C.; Spolidorio, D.M.P.; Bagnato, V.S.; Giusti, J.S.; Santos-Pinto, L. Photodynamic potential of curcumin and blue LED against Streptococcus mutans in a planktonic culture. Photodiagn. Photodyn. Ther. 2013, 10, 313-319. [CrossRef]

160. Araújo, N.C.; De Menezes, R.F.; Carneiro, V.S.M.; Dos Santos-Neto, A.P.; Fontana, C.R.; Bagnato, V.S.; Harvey, C.M.; Gerbi, M.E.M. Photodynamic inactivation of cariogenic pathogens using curcumin as photosensitizer. Photomed. Laser Surg. 2017, 35, 259-263. [CrossRef]

161. Penha, C.B.; Bonin, E.; Da Silva, A.F.; Hioka, N.; Zanqueta, É.B.; Ueda-Nakamura, T.; Filho, B.A.D.A.; Campanerut-Sá, P.A.Z.; Mikcha, J.M.G. Photodynamic inactivation of foodborne and food spoilage bacteria by curcumin. LWT Food. Sci. Technol. 2017, 76, 198-202. [CrossRef]

162. Aldred, E.M.; Buck, C.H.; Vall, K. Phenols. In Pharmacology, 1st ed.; Aldred, E.M., Buck, C.H., Vall, K., Eds.; Churchill Livingstone: London, UK, 2009; Chapter 21; pp. 149-166.

163. Llano, J.; Raber, J.; Eriksson, L.A. Theoretical study of phototoxic reactios of psoralens. J. Photoch. Photobiol. A 2003, 154, 235-243. [CrossRef]

164. National Institute of Diabetes and Digestive and Kidney Diseases. LiverTox: Clinical and Research Information on Drug-Induced Liver Injury [Internet]; Psoralen; National Institute of Diabetes and Digestive and Kidney Diseases: Bethesda, MD, USA, 2012. Available online: https://www.ncbi.nlm.nih.gov/books/NBK547880/ (accessed on 16 January 2020).

165. Harding, A.S.; Schwab, K.J. Using limes and synthetic psoralens to enhance solar disinfection of water (SODIS): A laboratory evaluation with norovirus, Escherichia coli, and MS2. Am. J. Trop. Med. Hyg. 2012, 86, 566-572. [CrossRef]

166. Ferruzzi, M.G.; Böhm, V.; Courtney, P.; Schwartz, S.J. Antioxidant and antimutagenic activity of dietary chlorophyll derivatives determined by radical scavenging and bacterial reverse mutagenesis assays. J. Food Sci. 2002, 67, 2589-2595. [CrossRef]

167. Chaturvedi, D.; Singh, K.; Sngh, V. Therapeutic and pharmacological aspects of photodynamic product chlorophyllin. Eur. J. Biol. Res. 2019, 9, 64-76.

168. Roca, M.; Chen, K.; Pérez-Gálvez, A. Chlorophylls. In Handbook on Natural Pigments in Food and Beverages; Chapter 6, Introduction to Plant Pharmacology; Reinhold, C., Schweiggert, R., Eds.; Woodhead Publishing: Sawston, Cambridge, UK, 2016; pp. 125-158. 
169. Rastogi, S.; Dwivedi, U.N. Porphyrin. In Biomolecules (Introduction, Structure and Functions); E-Book by Niscair; CSIR Publication: New Delhi, India, 2008; pp. 1-17.

170. Marquez, U.M.L.; Sinnecker, P. Chlorophylls: Properties, biosynthesis, degradation and functions. In Food Colorants: Chemical and Functional Properties, 1st ed.; Socaciu, C., Ed.; CRC Press: Boca Raton, FL, USA, 2007; pp. $25-45$.

171. Fahey, J.W.; Stephenson, K.K.; Dinkova-Kostova, A.T.; Egner, P.A.; Kensler, T.; Talalay, P. Chlorophyll, chlorophyllin and related tetrapyrroles are significant inducers of mammalian phase 2 cytoprotective genes. Carcinogenesis 2005, 26, 1247-1255. [CrossRef] [PubMed]

172. Wohllebe, S.; Richter, R.; Richter, P.; Häder, D.P. Photodynamic control of human pathogenic parasites in aquatic ecosystems using chlorophyllin and pheophorbid as photodynamic substances. Parasitol. Res. 2019, 104, 593-600. [CrossRef] [PubMed]

173. Lopezcarballo, G.; Hernandezmunoz, P.; Gavara, R.; Ocio, M. Photoactivated chlorophyllin-based gelatin films and coatings to prevent microbial contamination of food products. Int. J. Food Microbiol. 2008, 126, 65-70. [CrossRef]

174. Viera-Alcaide, I.; Pérez-Gálvez, A.; Roca, M. Green natural colorants. Molecules 2019, 24, 154. [CrossRef]

175. Buchovec, I.; Lukseviciūtè, V.; Kokstaite, R.; Labeikyte, D.; Kaziukonyte, L.; Luksiene, Z. Inactivation of Gram $(-)$ bacteria Salmonella enterica by chlorophyllin-based photosensitization: Mechanism of action and new strategies to enhance the inactivation efficiency. J. Photochem. Photobiol. B Biol. 2017, 172, 1-10. [CrossRef]

176. Kreitner, M.; Wagner, K.H.; Alth, G.; Ebermann, R.; Foißy, H.; Elmadfa, I. Hematoporphyrin- and sodium chlorophyllin-induced phototoxicity towards bacteria and yeasts-A new approach for safe foods. Food Control 2001, 12, 529-533. [CrossRef]

177. Luksiene, Z.; Kokstaite, R.; Katauskis, P.; Skakauskas, V. Novel approach to effective and uniform inactivation of gram-positive Listeria monocytogenes and gram-negative Salmonella enterica by photosensitization. Food Technol. Biotechnol. 2013, 51, 338-344.

178. Luksiene, Z.; Buchovec, I.; Paskeviciute, E. Inactivation of several strains of Listeria monocytogenes attached to the surface of packaging material by Na-Chlorophyllin-based photosensitization. J. Photochem. Photobiol. B Biol. 2010, 101, 326-331. [CrossRef] [PubMed]

179. Luksiene, Z.; Paskeviciute, E. Microbial control of food-related surfaces: Na-Chlorophyllin-based photosensitization. J. Photochem. Photobiol. B Biol. 2011, 105, 69-74. [CrossRef]

180. López-Carballo, G.; Hernández-Muñoz, P.; Gavara, R. Photoactivated self-sanitizing chlorophyllin-containing coatings to prevent microbial contamination in packaged food. Coatings 2018, 8, 328. [CrossRef]

181. Luksiene, Z.; Buchovec, I. Impact of chlorophyllin-chitosan coating and visible light on the microbial contamination, shelf life, nutritional and visual quality of strawberries. Innov. Food Sci. Emerg. Technol. 2019, 52, 463-472. [CrossRef]

182. Richter, P.R.; Krüger, M.; Prasad, B.; Gastiger, S.; Bodenschatz, M.; Wieder, F.; Burkovski, A.; Geißdörfer, W.; Lebert, M.; Strauch, S.M. Using colistin as a trojan horse: Inactivation of gram-negative bacteria with chlorophyllin. Antibiotics 2019, 8, 158. [CrossRef] [PubMed]

183. Foggiato, A.A.; Silva, D.F.; Castro, R.C.F.R. Effect of photodynamic therapy on surface decontamination in clinical orthodontic instruments. Photodiagn. Photodyn. Ther. 2018, 24, 123-128. [CrossRef] [PubMed]

184. Foggiato, A.A.; Garcez, A.S.; Fuziy, A.; Silva, D.F.; Foggiato, A.A.; Garcez, A.S.; Fuziy, A.; Silva, D.F. Photodynamic therapy: Alternative in decontamination of surfaces. In Proceedings of the SPIE 11223, Photonic Diagnosis, Monitoring, Prevention, and Treatment of Infections and Inflammatory Diseases 2020, San Francisco, CA, USA, 28 February 2020; 112230K.

185. Tiwana, A.S. Antimicrobial Photodynamic Treatment for Surface Sanitation. Master's Thesis, University of Guelph, Guelph, ON, Canada, 2006.

186. Vollmer, A.; Al-Ahmad, A.; Argyropoulou, A.; Thurnheer, T.; Hellwig, E.; Attin, T.; Vach, K.; Wittmer, A.; Ferguson, K.; Skaltsounis, A.L.; et al. Antimicrobial photoinactivation using visible light plus water-filtered infrared-a (vis + wira) and hypericum perforatum modifies in situ oral biofilms. Sci. Rep. 2019, 9, 20325. [CrossRef]

187. Josewin, S.W.; Ghate, V.; Kim, M.-J.; Yuk, H.-G. Antibacterial effect of $460 \mathrm{~nm}$ light-emitting diode in combination with riboflavin against Listeria monocytogenes on smoked salmon. Food Control. 2018, 84, 354-361. [CrossRef] 
188. Khan, S.; Rayis, M.; Rizvi, A.; Alam, M.; Rizvi, M.; Naseem, I. ROS mediated antibacterial activity of photoilluminated riboflavin: A photodynamic mechanism against nosocomial infections. Toxicol. Rep. 2019, 6, 136-142. [CrossRef]

189. Ruane, P.H.; Edrich, R.; Gampp, D.; Keil, S.D.; Leonard, R.L.; Goodrich, R.P. Photochemical inactivation of selected viruses and bacteria in platelet concentrates using riboflavin and light. Transfusion 2004, 44, 877-885. [CrossRef]

190. Huang, J.; Chen, B.; Li, H.; Zeng, Q.-H.; Wang, J.J.; Liu, H.; Pan, Y.; Zhao, Y. Enhanced antibacterial and antibiofilm functions of the curcumin-mediated photodynamic inactivation against Listeria monocytogenes. Food Control. 2020, 108, 106886. [CrossRef]

191. Méndez, D.A.C.; Gutierrez, E.; Lamarque, G.C.C.; Rizzato, V.L.; Buzalaf, M.A.R.; Machado, M.A.A.M.; Cruvinel, $\mathrm{T}$. The effectiveness of curcumin-mediated antimicrobial photodynamic therapy depends on pre-irradiation and biofilm growth times. Photodiagn. Photodyn. Ther. 2019, 27, 474-480. [CrossRef] [PubMed]

192. Yang, M.-Y.; Chang, K.C.; Chen, L.Y.; Hu, A. Low-dose blue light irradiation enhances the antimicrobial activities of curcumin against Propionibacterium acnes. J. Photochem. Photobiol. B Biol. 2018, 189, 21-28. [CrossRef] [PubMed]

193. Jiang, Y.; Leung, W.-N.; Hua, H.; Rao, X.; Xu, C. Photodynamic action of LED-activated curcumin against Staphylococcus aureus involving intracellular ROS increase and membrane damage. Int. J. Photoenergy 2014, 2014, 637601. [CrossRef]

194. Ribeiro, A.P.D.; Pavarina, A.C.; Dovigo, L.N.; Brunetti, I.L.; Bagnato, V.S.; Vergani, C.E.; Costa, C.A.D.S. Phototoxic effect of curcumin on methicillin-resistant Staphylococcus aureus and L929 fibroblasts. Lasers Med. Sci. 2012, 28, 391-398. [CrossRef] [PubMed]

195. Bonifácio, D.; Martins, C.; David, B.; Lemos, C.; Almeida, A.; Cunha, Â.; Neves, M.; Pinto, D.; Faustino, M.A.F. Photodynamic inactivation of Listeria innocua biofilms with food-grade photosensitizers: A curcumin-rich extract of Curcuma longa vs. commercial curcumin. J. Appl. Microbiol. 2018, 125, 282-294. [CrossRef]

196. Bulit, F.; Grad, I.; Manoil, D.; Simon, S.; Wataha, J.C.; Filieri, A.; Feki, A.; Schrenzel, J.; Lange, N.; Bouillaguet, S. Antimicrobial activity and cytotoxicity of 3 photosensitizers activated with blue light. J. Endod. 2014, 40, 427-431. [CrossRef]

197. Walther, J.; Bröcker, M.J.; Wätzlich, D.; Nimtz, M.; Rohde, M.; Jahn, D.; Moser, J. Protochlorophyllide: A new photosensitizer for the photodynamic inactivation of Gram-positive and Gram-negative bacteria. FEMS Microbiol. Lett. 2008, 290, 156-163. [CrossRef]

198. Caires, A.R.; Leal, C.R.B.; Ramos, C.A.N.; Bogo, D.; Lima, A.R.; Arruda, E.J.; Oliveira, S.L.; Melnikov, P. Photoinactivation effect of eosin methylene blue and chlorophyllin sodium-copper against Staphylococcus aureus and Escherichia coli. Lasers Med. Sci. 2017, 3, 1081-1088. [CrossRef]

199. Aponiene, K.; Luksiene, Z. Effective combination of LED-based visible light, photosensitizer and photocatalyst to combat Gram (-) bacteria. J. Photochem. Photobiol. B Biol. 2015, 142, 257-263. [CrossRef] [PubMed]

200. Buchovec, I.; Pamedytyte, R.; Gruskiene, R.; Luksiene, Z. Novel approach to the microbial decontamination of wheat sprouts: Photoactivated chlorophyllin-chitosan complex. In Industrial, Medical and Environmental Applications of Microorganisms; Mendez-Vilas, A., Ed.; Vageningen Academic: Madrid, Spain, 2013; pp. 352-356.

201. Buchovec, I.; Lukseviciute, V.; Marsalka, A.; Reklaitis, I.; Luksiene, Z. Effective photosensitization-based inactivation of Gram (-) food pathogens and molds using the chlorophyllin-chitosan complex: Towards photoactive edible coatings to preserve strawberries. Photochem. Photobiol. Sci. 2016, 15, 506-516. [CrossRef] [PubMed]

(C) 2020 by the authors. Licensee MDPI, Basel, Switzerland. This article is an open access article distributed under the terms and conditions of the Creative Commons Attribution (CC BY) license (http://creativecommons.org/licenses/by/4.0/). 